\title{
Terjemahan Beranotasi Kata dan Ungkapan Budaya di dalam Novel Anak Selandia Baru I'm Telling on You dan Barry \& Bitsa
}

\author{
Era Bawarti \\ Program Studi Sastra Inggris, Fakultas Sastra, Universitas Al Azhar Indonesia \\ Jln. Sisingamangaraja, Kebayoran Baru, Jakarta Selatan \\ Penulis untuk Korespondensi/E-mail: era.sugiri@uai.ac.id
}

\begin{abstract}
Abstrak - Penelitian ini adalah sebuah penelitian di bidang kajian terjemahan berupa terjemahan beranotasi, yakni terjemahan dengan catatan. Teks sumber (TSu) yang dipilih adalah novel anak Selandia Baru dari seri Kiwi Bites berjudul I'm Telling on You dan Barry \& Bitsa. Teks ini dipilih karena merupakan karya dari penulis yang sama dan ditulis dalam Bahasa Inggris dialek Selandia Baru yang memiliki sejumlah perbedaan dengan Bahasa Inggris standar. Selain itu, teks ini jika diterjemahkan juga potensial untuk menjadi bacaan anak yang bermutu. Analisis difokuskan pada terjemahan kata dan ungkapan budaya. Kerangka teori yang digunakan di dalam analisis adalah teknik penerjemahan dari Hoed (2006). Kata dan ungkapan budaya yang dibahas dalam penelitian ini sebanyak 15 buah. Dari hasil analisis ditemukan bahwa teknik penerjemahan yang digunakan paling sering adalah pemadanan dengan keterangan tambahan. Hal ini menunjukkan bahwa kata dan ungkapan budaya dalam TSu seringkali tidak memiliki padanan leksikalnya dalam bahasa sasaran (BSa).
\end{abstract}

Abstract - This study is a research in translation studies, namely annotated translation, i.e. translation with notation. Source text (ST) chosen is two New Zealand children's novel from Kiwi Bites series titled I'm Telling on You and Barry \& Bitsa. Both are chosen for both are the works of the same author as well as written in New Zealand English which has several differences with that of Standard English. Besides, the text is also potential to become a qualified children's reading, if translated. The analysis is focused on the translation of cultural words and terms. Theoretical framework used is translation technique (Hoed, 2006). Cultural words and terms discussed are as many as 15 items. The results show that translation techniques used more frequent are equivalence with notation. This means, most of cultural words and terms in ST have no lexical equivalence in the target language (TL).

Keywords: annotated translation, cultural word and term, translation technique.

\section{PENDAHULUAN}

Latar Belakang

Penelitian ini merupakan sebuah penelitian kajian terjemahan berupa terjemahan beranotasi. Terjemahan beranotasi sendiri adalah sebuah kegiatan penerjemahan dengan komentar atau penerjemahan bercatatan, yakni ketika seorang penerjemah memberikan komentar introspektif dan retrospektif terhadap penerjemahan yang dilakukannya (lihat Williams dan Chesterman, 2002, hlm. 7). Sebagaimana diketahui, seorang penerjemah harus dapat memberikan solusi bagi masalah penerjemahan yang dihadapinya ketika menerjemahkan sebuah teks. Oleh karena itu, ia juga harus memahami berbagai teori yang melandasi solusi bagi masalah penerjemahan yang dilakukannya. Pemahamannya tentang teori yang digunakannya ketika memberikan solusi ini dituangkan dalam bentuk komentar atas proses penerjemahan yang dilakukannya, sehingga dengan demikian penerjemah tidak hanya menerjemahkan tetapi juga memberikan komentar terhadap prosesnya. Adapun teks sumber (TSu) yang dipilih untuk diterjemahkan adalah novel anak I'm Telling on You dan Barry \& Bitsa karya penulis Selandia Baru, Sandy McKay. 
Kajian terjemahan sendiri merupakan bidang interdisipliner yang sempurna (really a perfect interdiscipline), karena beririsan dengan berbagai disiplin ilmu lain (Hatim dan Munday, 2004, hlm. 8). Tidak hanya dengan disiplin linguistik, kajian terjemahan juga beririsan dengan disiplin filsafat, rekayasa bahasa (language engineering), kajian budaya, dan kajian susastra (lihat bagan dalam Hatim dan Munday, 2004, hlm. 8). Dan akhirnya, sebagai sebuah bidang interdisipliner, kajian terjemahan pun menjadi disiplin tersendiri: bukan sekadar cabang dari kajian susastra bandingan atau sebuah ranah dalam linguistik, melainkan sebuah lahan yang kompleks dengan berbagai ramifikasi/percabangan yang luas cakupannya (Bassnett, 2003, hlm. 1).

Berkaitan dengan peririsannya dengan kajian susastra, beberapa ancangan dalam kajian terjemahan telah berkontribusi secara siginifikan terhadap teori susastra secara keseluruhan (Lefevere, 2004, hlm. 239). Penerjemahan juga memainkan peran penting dalam evolusi kesusastraan (Lefevere, 2004, hlm. 239). Terjemahan sebagai suatu praktik bahkan terbukti dapat menjembatani kesenjangan antara disiplin lingustik dan susastra (Newmark, 1991, hlm. 163).

Lebih lanjut, kajian terjemahan berguna dalam meneliti penerjemahan karya sastra. Penerjemahan karya sastra seperti prosa atau puisi berbeda dengan penerjemahan karya nonsastra. Menurut Israël (1996, hlm. 1), penerjemahan sastra muncul sebagai lahan konflik antara isi dan bentuk, namun sekaligus merupakan tindak komunikatif yang harus menyentuh rasa dan menciptakan efek. Menyentuh rasa dan menciptakan efek ini penting dalam penerjemahan sastra karena dua hal inilah yang terkandungi dalam TSu-nya. Bahasa susastra senantiasa menghadirkan "eksploitasi kreatif" dari berbagai potensi yang terkandungi dalam sebuah bahasa (Coseriu, 1971, lihat Snell-Hornby, 1995, hlm. 70), dan untuk menerjemahkan apa yang disebut "eksploitasi kreatif" ini dari bahasa aslinya ke bahasa lain dibutuhkan kerja keras dari si penerjemah agar tercapai kesepadanan. Upaya mencapai kesepadanan itulah yang kemudian menarik untuk diteliti dalam penelitian kajian terjemahan berupa terjemahan beranotasi.

Selanjutnya, karya sastra yang diperuntukkan bagi pembaca sasaran anak-anak disebut sastra anak, yang merupakan genre tersendiri dalam khazanah susastra khususnya dan dunia tulis-menulis umumnya. Menurut Hunt (1994), sastra anak merupakan wilayah yang memperoleh perhatian khusus dalam ranah tulis-menulis karena memiliki beberapa ciri khas, yakni

(S)alah satu akar budaya Barat, dinikmati tidak hanya oleh anak tetapi juga oleh orang dewasa, telah berhasil mengasah banyak bakat di bidang tulismenulis, melibatkan dan memadukan kata-kata dengan gambar-gambar, dan dapat ditranformasikan ke dalam berbagai moda: gambar bergerak, pembacaan cerita (story-telling) lisan, dan sebagainya" (Hunt, 1994, hlm. 1).

Sastra anak juga menarik karena merupakan jenis sastra yang diperuntukkan bagi anak namun kebanyakan ditulis/diproduksi oleh orang dewasa sehingga sering kali hanya merupakan bentuk lebih "sederhana" dari sastra dewasa dan tidak bersifat eksploratoris dan/atau mengandung pesan yang memperluas khazanah pengetahuan dan pemikiran anak sebagaimana yang seharusnya terdapat dalam karya sastra anak (lihat Hunt, 1994, hlm. 3-4). Berkaitan dengan penerjemahannya, sastra anak juga diterjemahkan oleh orang dewasa. Ini yang membuat sastra anak merupakan sesuatu yang unik dan menarik guna diteliti, yakni tentang bagaimana penerjemah yang merupakan orang dewasa menerjemahkan ragam dan laras bahasa anak dari BSu ke BSa.

\section{Rumusan Masalah}

Penelitian ini menjawab rumusan masalah berikut ini: teknik penerjemahan apa saja yang digunakan ketika menerjemahkan kata dan ungkapan budaya dalam teks novel anak I'm Telling on You dan Barry \& Bitsa?

\section{Tujuan Penelitian}

Penelitian ini bertujuan menginvestigasi proses penerjemahan yang dilakukan terhadap kata dan ungkapan budaya dengan merujuk kepada teknik penerjemahan menurut Hoed (2006).

\section{Manfaat Penelitian}

Secara praktis, novel I'm Telling on You dan Barry \& Bitsa merupakan teks yang menarik untuk diterjemahkan karena memiliki unsur budaya Barat yang dapat menambah khazanah pengetahuan anakanak Indonesia. Selain itu, tidak seperti novel berbahasa Inggris lain, kedua novel ini menggunakan bahasa Inggris dialek Selandia Baru yang mengandungi kosa kata yang tidak terdapat dalam kosa kata bahasa Inggris standar. Lantaran kisahnya yang menarik, terjemahan novel ini berpotensi untuk diterbitkan, dan dapat menjadi 
awal bagi penerjemahan dan penerbitan Seri Kiwi Bites di Indonesia.

Secara teoretis, penelitian ini akan memperkaya ragam penelitian di bidang kajian terjemahan, khususnya terjemahan novel anak dari Bahasa Inggris ke Bahasa Indonesia, terutama novel Bahasa Inggris dialek Selandia baru. Diharapkan penelitian terhadap novel Selandia Baru ini dapat berguna bagi pengembangan ilmu dalam kajian terjemahan.

\section{KERANGKA TEORI}

Bagian ini membahas teori penerjemahan yang digunakan sebagai landasan dalam melakukan penerjemahan dan mencari solusi bagi masalah penerjemahan yang ditemui selama proses menerjemahkan. Menurut Hidayat (2010, hlm. 65), kerangka teori dapat diibaratkan sebagai jendela yang dibuat atau dipilih oleh peneliti untuk dapat mengamati gejala yang terjadi di luar dirinya. Jadi, kerangka teori bersifat sangat pribadi: setiap peneliti menyusunnya sesuai dengan topik dan masalah penelitiannya (Hidayat, 2010, hlm. 65). Adapun kerangka teori yang digunakan dalam penelitian ini adalah teknik penerjemahan.

Menurut Hoed, teknik penerjemahan berguna untuk menanggulangi kesulitan penerjemahan pada tataran kata, kalimat, atau paragraf (2006, hlm. 72-78). Istilah "teknik" adalah istilah yang dikemukakan oleh Hoed (2006). Adapun Vinay dan Darbelnet (1958) dan Newmark (1988) menyebutnya "prosedur". Lebih lanjut, Vinay dan Darbelnet mengelompokkan berbagai prosedur ini ke dalam dua golongan besar yakni penerjemahan langsung (direct translation) dan penerjemahan bebas (oblique translation). Dalam penelitian ini saya memilih menggunakan istilah "teknik" dengan mengacu pada Hoed untuk mempermudah saya dalam memberi penjelasan pada bagian anotasi, walaupun ada sebagian dari teknik di bawah ini yang bukan dikutip dari Hoed.

\section{Transferensi}

Transferensi adalah proses mentransfer kata dalam BSu ke dalam TSa (Newmark, 1988, hlm. 81). Hoed menyebutnya "tidak diberikan padanan", atau mengutip saja bahasa aslinya karena penerjemah tidak dapat menemukan terjemahannya dalam BSa (2006, hlm. 77). Vinay dan Darbelnet menyebutnya sebagai prosedur borrowing yang selain merupakan prosedur termudah dari semua prosedur penerjemahan juga dapat menciptakan efek stilistis
(2004, hlm. 129). Teknik borrowing dilakukan untuk menerjemahkan kata skateboard berikut ini.

(TSu) 'Leave him alone,' shouts Billy, zipping onto the footpath with his skateboard.

(Terjemahan) "Jangan ganggu dia," teriak Billy, tiba-tiba saja melintas di trotoar dengan skateboard-nya.

Contoh di atas memperlihatkan bahwa kata skateboard tidak diterjemahkan, melainkan dipungut begitu saja di dalam terjemahannya. Pertimbangannya adalah karena kata ini sudah cukup dikenal dalam budaya sasaran.

Selain borrowing yang diterapkan pada tingkat kata, teknik transferensi juga dapat diterapkan pada tingkat lebih luas dari kata, seperti frasa dan klausa/kalimat. Biasanya bentuk frasa atau klausa/kalimat ini berupa ungkapan atau istilah yang idiomatis atau yang sudah sangat populer dalam BSu. Teknik transferensi jenis ini disebut oleh Vinay dan Darbelnet disebut calque. Calque dijuluki juga "a special kind of borrowing" (Vinay dan Darbelnet, 2004, hlm. 129) karena BSa meminjam begitu saja sebuah ungkapan dari BSu lalu menerjemahkan secara harfiah. Contoh:

(TSu) 'Bitsa,' I stroked the hard flat head. His ears were real silky. 'Cool name.'

(Terjemahan) "Bitsa." Kubelai kepala Bitsa yang datar. Kupingnya selembut sutera. "Nama yang keren."

Dari contoh di atas tampak bahwa frasa real silky diterjemahkan secara harfiah menjadi selembut sutera. Hal ini dilakukan mengingat dalam budaya sasaran istilah selembut sutera juga digunakan untuk menggambarkan sesuatu yang amat halus dan lembut, sehingga pemadanan ini wajar dan berterima.

Lebih lanjut, baik borrowing maupun calque menurut Vinay dan Darbelnet merupakan teknik penerjemahan langsung.

\section{Padanan deskriptif}

Padanan deskriptif (descriptive equivalence). adalah membuat uraian mengenai makna kata ybs karena padanannya tidak ditemukan, baik karena penerjemah tidak tahu maupun karena padanannya tidak ada/belum ada dalam BSu (Hoed, 2006, hlm. 74). Contoh:

(TSu) Serves him right, I think. (Terjemahan) Hukuman yang setimpal, menurutku. 
Ungkapan serves him right tidak dapat dijabarkan berdasarkan kata-kata yang membentuknya. Menurut LDOCE (2001, hlm. 1301), it serves sb right maknanya adalah "spoken used to say that you think someone deserves it if something unpleasant happens to them, because they have been stupid or unkind". Ungkapan ini tidak ada padanannya dalam BSa, sehingga pemadannya adalah dengan memberikan deskripsi dari makna ungkapan tersebut.

\section{Padanan fungsional}

Menurut Newmark (1988, hlm. 83), teknik ini diterapkan pada kata-kata yang bersifat budaya BSu (cultural words). Penerjemahan kata-kata semacam ini adalah dengan mencari padanannya dalam BSa berupa kata yang bebas dari unsur/sifat budaya (culture-free word), terkadang dengan istilah baru yang spesifik sehingga kata itu terasa lebih netral atau umum dalam TSa-nya. Teknik ini adalah cara yang paling akurat dalam melakukan dekulturalisasi terhadap kata tertentu yang unsur budayanya kuat, seperti misalnya kata slang. Menurut Keraf (2001, hlm. 108), kata slang adalah kata-kata nonstandar yang informal, yang disusun secara khas; atau kata-kata biasa yang diubah secara arbitrer; atau kata-kata kiasan yang khas, bertenaga, dan jenaka yang dipakai dalam percakapan. Masih menurut Keraf (2001, hlm. 108), kata slang bertolak dari keinginan agar bahasa itu lebih hidup dan asli.

Dalam TSu, saya menemukan tiga kata slang yakni bogey, chook, dan honker. Kata bogey dan honker saya terjemahkan dengan padanan fungsionalnya sehingga nuansa budayanya sama sekali hilang, namun makna yang dimaksud oleh penulis TSu menjadi tersampaikan, sedangkan kata chook yang merupakan bagian dari idiom like a chook with its head cut off saya bebaskan dulu dari nuansa slangnya sehingga idiomnya menjadi jelas, yakni like a chicken with its head cut off (cetak tebal dari sayapen.). Setelah itu barulah saya mencari makna idiom tersebut dan kemudian menerjemahkannya.

\section{Padanan budaya}

Teknik ini memberikan padanan berupa unsur kebudayaan yang ada dalam BSa (Hoed, 2006, hlm. 78). Teknik ini diterapkan ketika menerjemahkan onomatope, idiom atau ungkapan idiomatis, simile dan metafora, serta istilah yang sudah ada padanannya dalam BSa. Contohnya adalah sebagaimana berikut ini, yakni ketika istilah Xmas diterjemahkan menjadi hari Natal.
(TSu) Sexist stereotyping is the reason I get plastic teaset for Xmas.

(Terjemahan) Agar terhindar dari stereotip jenis kelamin, pada hari Natal aku dihadiahi satu set perangkat minum teh mainan dari plastik.

\section{Modulasi}

Modulasi adalah memberikan padanan yang secara semantik berbeda sudut pandang artinya atau cakupan maknanya, tetapi dalam konteks yang bersangkutan memberikan pesan/maksud yang sama (Hoed, 2006, hlm. 74). Teknik ini juga dikemukakan pertama kali oleh Vinay dan Darbelnet dengan definisi "variasi bentuk pesan dengan cara mengubah sudut pandang" (2004, hlm.133). Teknik ini dapat dibenarkan ketika terjemahannya, ketika diterjemahkan baik harfiah maupun transposisional (mengubah kelas kata atau struktur kalimat), terasa tidak berterima secara gramatikal, tidak idiomatis (jika berupa idiom), tidak wajar, dan sebagainya (2004, hlm. 133). Teknik ini oleh Vinay dan Darbelnet digolongkan ke dalam penerjemahan bebas. Contoh:

(TSu) The longest bogey-catcher I'd seen in my life. (Terjemahan) Benar-benar hidung paling megar yang pernah kulihat!

Di sini terlihat adanya perubahan cakupan makna dari the longest menjadi paling megar. Perubahan ini bertujuan untuk menghadirkan terjemahan yang lebih wajar dan berterima sesuai konteks yang melingkupi ungkapan tersebut, karena hidung yang dimaksud di sini tidak semata-mata panjang melainkan juga besar. Kedua citra tersebut direpresentasikan dengan kata megar.

\section{Kuplet}

Teknik yang diperkenalkan oleh Newmark (1988, hlm. 91) ini menggabungkan dua teknik sekaligus untuk memberi solusi atas satu masalah penerjemahan. Teknik ini biasanya dilakukan dalam menerjemahkan kata budaya. Contoh:

(TSu) He's even offered to make them a half-pipe.

(Terjemahan) Dia bahkan menawarkan untuk membuatkan vert - itu lho, papan lengkung besar untuk landasan atraksi skateboard.

Istilah half-pipe dalam BSa berpadanan dengan vert. Pemadanan ini menggunakan teknik padanan budaya. Akan tetapi vert saja dirasa belum memadai untuk menyampaikan makna kata halfpipe sehingga saya memberi deksripsinya setelah tanda hubung. Pemadanan ini menggunakan teknik 
penerjemahan deskriptif. Gabungan kedua teknik ini merupakan bentuk kuplet.

\section{Padanan fonologis}

Teknik ini digunakan ketika penerjemah tidak dapat menemukan padanan yang sesuai dalam BSa sehingga ia memutuskan untuk membuat kata baru yang diambil dari bunyi kata itu dalam BSu untuk disesuaikan dengan sistem bunyi (fonologi) dan sistem ejaan (grafologi) BSa (Hoed, 2006, hlm. 76). Newmark (1988, hlm. 82) menyebutnya naturalisasi, yakni sebuah prosedur yang meliputi pemindahan dan pengadaptasian sebuah kata dari $\mathrm{BSu}$ ke BSa, diawali dengan transfer pelafalan dan diakhiri dengan adaptasi morfologis. Dalam teks ini, contohnya adalah, misalnya, sebagaimana yang saya bahas pada Bab 5 bagian 5.3.4 tentang makanan, yakni sausage casserole (lihat par. 320 pada TSu dan terjemahan), kata fantastic yang diterjemahkan menjadi fantastis (par. 140), dan kata pie yang diterjemahkan menjadi kue pai (par. 321).

\section{Pemadanan dengan keterangan tambahan}

Menurut Machali (2009, hlm. 103), apabila semua teknik penerjemahan tidak dapat menghasilkan padanan yang diharapkan, langkah yang dapat dilakukan adalah dengan pemadanan bercatatan. Hal ini berlaku misalnya dalam penerjemahan kata atau ungkapan yang padanan leksikalnya sama sekali tidak ada dalam BSa. Contoh (dikutip dari Machali, 2009, hlm. 103):

(TSu) Doodgeridoo is a traditional musical instrument used by the Aborigines.

(Terjemahan) Doodgeridoo adalah alat musik tradisional yang digunakan oleh orang Aborigin. (catatan: Doodgeridoo adalah alat musik yang bentuknya seperti seruling panjang, dengan ujung yang melengkung dan mengeluarkan bunyi seperi sirine kapal laut yang akan berangkat.)

Contoh di atas adalah yang biasa dilakukan dalam jenis teks nonfiksi. Pemberian catatan semacam itu wajar dan berterima dalam terjemahan teks nonfiksi. Adapun dalam teks fiksi, apalagi dalam novel anak, teknik semacam itu tidak dapat diterapkan. Penerjemah harus lebih kreatif lagi dalam merangkai kata agar hal yang tidak ada padanannya namun tidak dapat dipungut begitu saja ke dalam BSa ini dapat diterjemahkan secara wajar dan berterima. Untuk kepentingan itu, Newmark (1988) memberikan solusinya. Menurutnya, pemadanan dengan keterangan tambahan dapat menjadi solusi bagi masalah ini.
Ada macam-macam varian keterangan tambahan yang ditawarkan oleh Newmark (1988, hlm. 91-93). Akan tetapi, menurut saya, dalam teks fiksi seperti novel anak, keterangan tambahan sebaiknya berada di dalam teks, tidak dalam bentuk catatan kaki, catatan akhir, atau glosarium. Teknik ini saya terapkan dalam terjemahan novel anak ini. Hal ini bertujuan untuk menghindari terusiknya alur perhatian pembaca dari jalan cerita yang sedang berjalan. Contoh:

(TSu) And Billy's trying to show me how to olly [...]. (Terjemahan) Dan Billy memperlihatkan padaku bagaimana cara melakukan olly. Kuberi tahu ya: olly itu atraksi meloncat dari papan skateboard yang sedang meluncur, lalu mendarat lagi di atasnya.

Pada contoh di atas, terlihat bahwa saya menggunakan pemadanan dengan keterangan tambahan berupa keterangan bentuk deskripsi dari kata/frasa yang dimaksud pada kalimat berikutnya. Varian lain dari teknik ini adalah dengan memberi tanda kurung setelah kata/frasa yang dimaksud. Contoh:

(TSu) Perhaps in the next innings I'd be allowed a bat. (Terjemahan) Mungkin di inning (babak) berikutnya aku diijinkan memukul.

Varian lain dari pemadanan semacam ini adalah penjelasan tambahan, yakni memberikan tambahan kata khusus untuk menjelaskan suatu kata yang masih dianggap asing oleh khalayak pembaca TSa (Hoed, 2006, hlm. 74). Nida dan Taber (1974, hlm. 109-110) menyebutnya sebagai penyelarasan kontekstual, yakni teknik yang dilakukan dengan menambahkan kata-kata khusus (classifier) untuk menjelaskan istilah dalam BSu yang belum atau tidak ada padanannya dalam BSa. Contoh :

(TSu) She was boss of the tele, which meant I hardly ever got to watch 'The Simpsons'.

(Terjemahan) Dia juga penguasa televisi. Artinya, aku jadi tidak bias menyaksikan film seri kartun "The Simpsons" kalau ada dia.

Contoh di atas memperlihatkan bahwa konteks kalimat TSu mengharuskan penerjemah menghadirkan frasa film seri kartun di depan nama diri The Simpsons. Dalam hal ini penerjemah melakukan penyelarasan kontekstual. Penyelerasan ini dilakukan untuk memperjelas makna The Simpsons yang dimaksud dalam konteks kalimat di atas, yakni film seri kartun yang ditayangkan di televisi dan bukan versi layar lebarnya. 
Lebih lanjut, pemadanan semacam ini memang cukup berguna guna membuat pembaca sasaran paham akan makna kata/istilah yang dimaksud. Apalagi TSa-nya ditujukan untuk anak-anak yang baik pengetahuan $\mathrm{BSu}$ maupun pengetahuan umumnya belum terlampau banyak. Meskipun demikian, frekuensi penggunaan teknik pemadanan semacam ini saya upayakan sesedikit mungkin, karena penerapan teknik ini yang terlalu kerap akan menimbulkan kekaburan antara mana yang isi teks sesungguhnya dan mana yang merupakan kontribusi penerjemah (lihat Newmark, 1988, hlm. 92).

\section{Adaptasi}

Teknik ini diterapkan ketika penerjemah menemui masalah yang tingkat kesulitannya sangat tinggi. Vinay dan Darbelnet menyatakannya sebagai extreme limit of translation, yakni ketika situasi yang digambarkan oleh TSu sama sekali asing dalam budaya sasaran. Dalam kasus semacam ini, penerjemah harus menciptakan situasi "baru" yang diangga(p sepadan dengan situasi yang digambarkan oleh TSu (Vinay dan Darbelnet, 2004, hlm. 135). Contohnya adalah ketika saya menciptakan situasi baru untuk materi puitis 'Telltale tit. Your tongue shall be split. And all the little puppy dogs will have a little bit!' (par. 33), ketika menerjemahkan kalimat pada paragraf 52-55 dan 58-59 yang mengandungi masalah dialek tokoh Frank Piper, dan ketika memadankan ungkapan bee brain dengan otak kopong (par. 323).

Kesemua teknik tersebut di atas akan menjadi alat introspeksi bagi penerjemah ketika akan membuat anotasi terhadap penerjemahannya, yang merupakan hasil retrospeksi.

\section{METODE PENELITIAN}

Penelitian ini sejatinya merupakan satu aspek saja dari sebuah penelitian besar terjemahan beranotasi terhadap novel I'm Telling on You dan Barry \& Bitsa. Dalam hal ini, saya hanya berfokus pada terjemahan kata budaya saja. Penelitian ini juga merupakan studi kepustakaan, mengingat bahwa: (1) peneliti berhadapan langsung dengan teks dan bukan dengan pengetahuan langsung dari lapangan atau saksi mata; (2) data yang digunakan bersifat siap pakai (ready-made), yang artinya peneliti tidak pergi ke mana-mana, melainkan hanya berhadapan langsung dengan sumber yang sudah tersedia di perpustakaan; (3) data yang digunakan adalah sumber sekunder, dalam arti peneliti memperolehnya dari tangan kedua dan bukan data orisinil dari lapangan, dan (4) kondisi data tidak dibatasi oleh ruang dan waktu, yang artinya dalam hal ini peneliti berhadapan dengan informasi statik yang sudah tersimpan dalam rekaman tertulis sebagai data "mati" (lihat Zed, 2014, hlm. 4-5). Selain sebagai studi kepustakaan, penelitian ini juga menggunakan metode kualitatif. Artinya, peneliti hanya akan berurusan dengan data non-numerikal yang dianalisis menggunakan metode non-statistik (Dornyei, 2007), dan memiliki bentuk rumusan masalah yang deskriptif, karena masalah yang diteliti menuntuk eksplorasi yang menyeluruh, luas, dan mendalam (Sugiyono, 2010).

\section{Teks Sumber}

Teks sumber adalah dua buah novel anak Selandia Baru dari serial Kiwi Bites, berjudul I'm Telling on You dan Barry \& Bitsa. I'm Telling on You terdiri dari 16 bab yang dituangkan ke dalam 95 halaman. Novel ini diterbitkan oleh Puffin Books pada 2006. Adapun Barry \& Bitsa terdiri dari 15 bab yang dituangkan dalam 96 halaman. Novel ini diterbitkan oleh Puffin Books pada 2005.

Teks I'm Telling on You dan Barry \& Bitsa ini dipilih karena keduanya merupakan novel anak yang menarik. Kisahnya berisi tentang hal seharisehari yang dialami anak-anak usia sekolah dasar. Menurut laman Wikipedia, kisah yang berisi tentang hal sehari-hari ini dikategorikan ke dalam genre fiksi dengan subgenre fiksi realistis (lihat http://en.wikipedia.org/wiki/Children\%27s_literatu re diakses pada 15 November 2010).

Secara singkat, I'm Telling on You mengedepankan kisah tentang tanggung jawab, sedangkan Barry \& Bitsa bercerita tentang hubungan anak dan orangtua. Adapun benang merah dari kedua novel ini adalah tentang penyelesaian masalah. Bagaimana tokoh Timothy dalam I'm Telling on You mencari solusi bagi masalah yang menimpanya diceritakan secara menarik. Konflik batin yang dialaminya, yang akhirnya bermuara pada keberaniannya mengakui kesalahan, dirangkai secara indah oleh penulis TSu. Persahabatannya dengan tokoh Billy-lah yang dikisahkan menguatkannya untuk mengaku. Hal ini karena persahabatan ini juga sangat bernilai bagi Timothy. Ia memperolehnya dengan susah-payah: setelah menghentikan kebiasaannya mengadu. Sesuatu yang berharga yang kita miliki baru terasa setelah kita kehilangannya, juga hadir dalam kisah Barry \& Bitsa. Hubungan ibu-anak yang selama ini kurang harmonis (karena ibunya sebagai orangtua tunggal 
terlalu sibuk bekerja mencari nafkah untuk menghidupi mereka berdua), diceritakan membaik justru ketika tokoh Barry tengah tertimpa masalah. Ibunya tersadar bahwa selama ini ia telah mengabaikan anaknya, dan akhirnya mendampingi Barry dalam menyelesaikan masalahnya. Masingmasing ide utama dalam kedua novel ini dijalin dalam jalan cerita yang khas anak-anak usia sekolah: selain berkelindanan dengan tokoh orang tua, juga diwarnai oleh kehadiran tokoh guru, orang dewasa lain, dan teman-teman baik yang antagonis maupun protagonis.

Selanjutnya, ada unsur budaya Barat, khususnya yang hadir dalam bentuk kata budaya, yang dapat menambah khazanah pengetahuan anak-anak Indonesia. Alasan ini juga menguatkan argumen saya tentang mengapa kedua novel ini menarik untuk diterjemahkan.

\section{Deskripsi Pengarang Novel}

Dari penelusuran dokumen yang saya lakukan di media daring seperti Longacre-Online, New Zealand Book Council, dan Storylines, diketahui bahwa penulis TSu adalah seorang wanita bernama Sandy McKay. Ia lahir pada tahun 1959, besar, dan hingga kini menetap di Dunedin, Selandia Baru, bersama suami dan ketiga anaknya. Gelar akademisnya adalah Bachelor of Arts (BA) di bidang Political Studies dari University of Otago, Selandia Baru.

Lebih lanjut, McKay berprofesi sebagai penulis buku anak dan penulis lepas. Ia secara rutin menulis kolom humor di Kiwi Parent Magazine. Salah satu novel anak karyanya, Recycled (Longracre Press, 2001), memperoleh penghargaan dalam New Zealand Post Children's Book Award tahun 2002 untuk kategori Junior Fiction. Novel ini terdaftar dalam Storylines Notable Young Adults Fiction Book tahun 2002. Adapun novel remaja pertamanya, Losing It (Longracre Press, 2007), dinominasikan untuk Esther Glen Award dalam New Zealand Post Children's Book Award tahun 2008, serta terdaftar dalam Storylines Notable Young Adults Fiction Book tahun 2008.

\section{Pembaca Teks}

Pembaca potensial TSu adalah pembaca serial Kiwi Bites sebagaimana yang tertera dalam laman internet http://www.wheelers.co.nz/browse/series (diakses pada 21 Juli 2010) yakni pembaca muda usia 7-12 tahun. Serial Kiwi Bites sendiri dalam bahasa sumbernya (BSu) diterbitkan dengan tujuan mengasah keterampilan membaca anak-anak usia 7-12 tahun. Diharapkan, setelah terampil membaca, kepercayaan diri mereka pun meningkat. Kisah-kisah dalam serial ini sendiri berpusar pada tema humor, kepercayaan diri, olahraga, petualangan, kasih-sayang, perjalanan, dan penyelesaian masalah.

Adapun pembaca potensial teks sasaran (TSa) menurut saya adalah anak usia 9-12 tahun, mengingat pada usia sekian umumnya pengetahuan umum anak Indonesia sudah cukup luas dan oleh karenanya dapat memahami pesan yang dibawa.

\section{Tahapan}

Tahapan penelitian yang digunakan dalam penelitian penerjemahan ini mengadopsi Larson (1984). Saya membaginya menjadi tiga bagian, yakni bagian pendeskripsian alat kerja dan narasumber, bagian penerjemahan, dan bagian anotasi.

\section{Alat Kerja dan Narasumber}

Alat kerja yang saya gunakan adalah beberapa buah kamus, yakni (i) Advanced English-Indonesian Dictionary karya Peter Salim terbitan Modern English Press tahun 1991, (ii) Kamus Besar Bahasa Indonesia Pusat Bahasa Depdiknas terbitan Gramedia Pustaka Utama tahun 2008, (iii) Kamus Indonesia-Inggris: $\quad$ An Indonesian-English Dictionary karya John M. Echols dan Hassan Shadily terbitan Gramedia Pustaka Utama tahun 1992, (iv) Kamus Inggris-Indonesia: An EnglishIndonesia Dictionary, juga karya John M. Echols dan Hassan Shadily terbitan Gramedia Pustaka Utama tahun 1998, (v) Longman Dictionary of Contemporary English terbitan Pearson Educational Limited tahun 2001, (vi) Oxford Advanced Learner's Dictionary of Current English terbitan Oxford University Press tahun 1995, dan (vii) The Concise Macquarie Dictionary terbitan Doubleday tahun 1992. The Concise Macquarie Dictionary (TCMD) ini penting untuk dijadikan rujukan mengingat $\mathrm{BSu}$ adalah bahasa Inggris dialek Selandia Baru yang memiliki beberapa ciri khas yang tidak serupa dengan bahasa Inggris standar. TCMD, yang merupakan edisi khusus dari The Macquarie Dictionary, sesungguhnya disusun sebagai kamus ekabahasa untuk bahasa Inggris dialek Australia. Meskipun demikian, menurut laman

http://en.wikipedia.org/wiki/Macquarie_Dictionary (diakses 23 Desember 2010), kamus ini juga memberi perhatian khusus pada bahasa Inggris dialek Selandia Baru, sehingga pemanfaatannya sebagai salah satu alat kerja dalam penelitian ini saya anggap relevan. 
Selain itu, saya juga memanfaatkan Tesaurus Alfabetis Bahasa Indonesia Pusat Bahasa Depdiknas terbitan Mizan tahun 2008. Saya pun mengunjungi laman daring seperti Dictionarist.com, Dictionary.net, Dictionary.reference.com, Encyclo.co.uk, Ensiklopedia Britannica daring, Idiomsite.com, Merriam-webster.com, Newzealandslang.com, Oldict.com, FreeDictionary, Urbandictionary.com, Webster's Online Dictionary, Wikipedia Bahasa Indonesia, Wikipedia English, Wiktionary, Wisegeek.com, serta dua buah blog: satu blog ranah olahraga dan satu blog ranah kulinari. Hal ini dilakukan guna mencari makna kata yang tidak saya temukan di dalam berbagai kamus di atas.

Berkenaan dengan narasumber yang menjadi mitra diskusi saya, saya memilih Nigel Murphy, M.A. (53), seorang WN Selandia Baru. Ia berprofesi sebagai peneliti di bidang sejarah komunitas etnis Cina Selandia Baru pada Victoria University of Wellington dan pustakawan di Alexander Turnbull Library, National Library of New Zealand. Ia pernah menetap di Australia pada kurun waktu 1963-1971, namun selebihnya ia tinggal di Selandia Baru. Murphy dipilih karena penguasaannya terhadap aspek budaya dari bahasa Inggris dialek Selandia Baru. Narasumber selanjutnya adalah Pevi Permana Putra (31), seorang atlet skateboard nasional asal Bandung, Jawa Barat. Ia sudah sering menjuarai turnamen skateboarding tingkat Asia. Nama Pevi Permana Putra saya temukan ketika menelusur di laman daring. Prestasinya di bidang skateboard membuatnya sesuai sebagai narasumber untuk menjelaskan beberapa istilah di bidang tersebut.

\section{Penerjemahan}

Penerjemahan dilakukan dalam dua tahap, yakni tahap produksi dan tahap pascaproduksi. Tahap produksi terdiri dari subtahap sebagai berikut.

1. Persiapan. Subtahap persiapan meliputi pencarian referensi dan penguatan pemahaman mengenai isi teks yang akan diterjemahkan. Referensi meliputi buku dan dokumen dari media daring. Saya juga mulai memanfaatkan alat kerja berupa kamus, tesaurus, glosarium, dan ensiklopedia, serta bertanya pada narasumber. Pada subtahap ini saya membaca TSu beberapa kali agar dapat memahami pesan yang ingin disampaikan oleh penulis TSu.

2. Analisis. Subtahap analisis adalah ketika saya mulai membuat ancangan teknik penerjemahan yang akan digunakan.
3. Pengalihan (transfer). Subtahap pengalihan dilakukan dalam benak/pikiran saya setelah pemahaman. Pada subtahap ini saya mulai mencari padanan yang tepat sesuai dengan pembaca sasaran sehingga diperoleh terjemahan yang wajar, berterima, dan sepadan. Saya juga melakukan adaptasi total pada beberapa unsur maknawi demi tersampaikannya maksud dari penulis $\mathrm{TSu}$ dalam tataran paragraf.

4. Pembuatan draf. Subtahap pembuatan draf dikerjakan pada tataran paragraf, serta berfokus pada khalayak pembaca sasaran (audience design), tujuan penerjemahan (need analysis), dan topik paragraf. Pada subtahap ini saya mulai melakukan penelusuran dokumen, memanfaatkan buku dan dokumen referensi, serta merujuk pada alat kerja. Untuk penelusuran dokumen daring, laman yang saya kunjungi (berdasarkan urutan alfabetis) adalah Anjingkita.com, bb.org.nz, BBC.co.uk, html.hist.no/PROSJEKT/Engnett/songar.doc, Gracegems.org, Kompasiana.com, LongacreOnline, New Zealand Book Council, NZembassy.com, NZhistory.net, Sabdaspace.com, Storylines, dan Wheelers.com. Saya juga mulai berdiskusi dengan narasumber untuk memastikan makna.

5. Evaluasi. Subtahap evaluasi yakni ketika saya memeriksa kohesi antarkalimat dan antarparagraf serta kesalahan ejaan, tanda baca, dll.

6. Perbaikan draf. Subtahap perbaikan draf bertujuan merevisi draf pertama berdasarkan hasil evaluasi

7. Draf akhir. Subtahap draf akhir dibuat berdasarkan evaluasi draf.

Setelah tahap produksi selesai, saya memasuki tahap pascaproduksi sebagai berikut.

1. Saya membandingkan TSa dengan TSu yang bertujuan mencocokkan kembali kesepadanan pesan sehingga tidak terjadi penyimpangan isi dan bentuk.

2. Saya meminta orang memeriksa pemahaman saya terhadap TSu. Hal ini dilakukan demi menjaga objektivitas. Adapun pemeriksa ini terdiri dari orang dewasa awam yang memahami bahasa sumber dan bahasa sasaran (bukan dari kalangan akademisi penerjemahan).

3. Saya menguji kewajaran terjemahan. Menguji kewajaran terjemahan ini dilakukakn oleh saya sendiri dan orang lain. Saya melakukannya dengan cara 
membandingkan terjemahan saya dengan bacaan anak terjemahan lain seperti novel dari serial Lima Sekawan berjudul Minggat (terbitan Gramedia Pustaka Utama tahun 1984) dan Trio Detektif berjudul Misteri Kemelut Kembar (terbitan Gramedia Pustaka Utama tahun 1988). Kedua novel ini diterjemahkan oleh Agus Setiadi. Sementara itu, uji kewajaran terjemahan yang melibatkan orang lain dilakukan oleh orang dewasa awam dan anak kelas 4-5 SD (usia 9-11 tahun, usia pembaca sasaran). Hal ini berguna untuk mengetahui apakah laras dan ragam bahasa sudah sesuai dengan pembaca sasaran.

4. Saya menguji konsistensi. Konsistensi berpengaruh terhadap keterbacaaan dan baikburuknya terjemahan serta menjamin alur cerita sehingga dapat diikuti dengan mudah. Agar terjemahan menjadi lebih luwes, saya memutuskan untuk mengabaikan konsistensi beberapa unsur leksikal agar kekayaan padanan leksikal sebagai ciri khas prosa dapat ditampilkan.

5. Apabila masih terdapat kekurangan dalan hal kesepadanan pesan, pemahaman, kewajaran, maupun konsistensi sebagai hasil dari uji kesepadanan pesan, pemahaman, kewajaran, dan konsistensi, maka dilakukan revisi berdasarkan masukan yang diperoleh dari uji-uji itu. Revisi ini diujikan kembali sesuai langkah-langkah di atas hingga diperoleh draf akhir yang optimal.

\section{Anotasi}

Setelah tahap produksi dan pascaproduksi terjemahan selesai, saya melakukan anotasi dengan tahapan sebagai berikut.

1. Saya mengidentifikasi berbagai masalah yang menarik untuk dianotasi yang terdapat dalam TSa. Masalah tersebut digolongkan ke dalam dua aspek, yakni (i) aspek linguistik atau kebahasaan dan (ii) aspek kultural atau kebudayaan. Untuk memecahkan masalah yang bersumber dari aspek kebahasaan, saya melihat kamus, tesaurus, ensiklopedia, dan melakukan tanya-jawab dengan narasumber. Untuk memecahkan masalah yang berkenaan dengan aspek kebudayaan, saya mengacu pada dua pilihan, yakni mempertahankan nuansa asingnya atau mengalihkannya ke dalam nuansa lokal. Pilihan tersebut diambil melalui proses setelah bertanya kepada narasumber tentang makna kata/frase/ungkapan itu.
2. Saya mengelompokkan berbagai masalah itu berdasarkan kategorinya. Dalam penelitian ini, yang saya fokuskan adalah masalah penerjemahan kata dan ungkapan yang bermuatan unsur budaya.

3. Saya menganotasi pilihan padanan yang merupakan solusi dari masalah dalam penerjemahan berdasarkan penelusuran dokumen. Solusinya digolongkan menurut teknik penerjemahannya.

Latar belakang yang menempatkan TSu sebagai sebuah karya sastra anak dengan segala kekhasannya serta langkah penerjemahan yang dipilah menjadi tahap produksi terjemahan dan pascaproduksi terjemahan di atas menjadi tumpuan saya dalam menerjemahkan TSu. Penerjemahan sastra anak sebagai sesuatu yang khas akan saya letakkan pada kerangka laras dan ragam bahasa yang digunakan dalam terjemahannya. Hal ini dikaitkan pula dengan pemosisian sastra anak sebagai karya fiksi, sehingga terjemahannya harus mengikuti prinsip-prinsip penerjemahan karya fiksi. Pilihan metode dan teknik penerjemahan serta laras dan ragam bahasa juga akan diselaraskan dengan fakta bahwa TSa akan dibaca oleh khalayak pembaca anak-anak dan bertujuan sebagai bacaan anak. Semua ini saya sampaikan pada bagian Hasil dan Analisis. Adapun kesimpulan dari pelbagai temuan yang dibahas pada bagian Hasil dan Analisis serta saran berkenaan dengan penelitian sejenis disampaikan pada bagian Simpulan.

\section{HASIL DAN PEMBAHASAN}

Kata atau ungkapan budaya adalah kata atau ungkapan yang tidak dapat langsung dipahami oleh pembaca sasaran karena muatan budaya sumbernya sangat kuat (lihat Newmark, 1988, hlm. 119). Sebagian besar kata dan ungkapan budaya mudah dideteksi kehadirannya, mengingat kata dan ungkapan semacam ini diasosiasikan dengan bahasa tertentu dan tidak dapat diterjemahkan secara harfiah (Newmark, 1998, hlm. 95). Untuk dapat membuat pembaca sasaran memahami apa yang dimaksud oleh kata tersebut, seorang penerjemah harus mampu menerapkan teknik penerjemahan yang cocok dengan tiap-tiap kata itu sehingga terjemahannya menjadi wajar dan berterima.

Ketika melakukan penerjemahan terhadap kata dan ungkapan bermuatan unsur budaya dalam TSu, setiap permasalahan diselesaikan dengan cara 
introspektif. Solusi ini kemudian dituangkan dalam bentuk catatan atau anotasi, sehingga penelitian ini merupakan penelitian terjemahan beranotasi.

Williams dan Chesterman mendefinisikan terjemahan beranotasi sebagai bentuk penelitian introspektif dan retrospektif (2002, hlm. 7). Introspektif adalah menelaah ke dalam diri penerjemah sendiri tentang makna suatu kata/frasa/klausa/ungkapan, lalu menuangkan makna tersebut dengan padanan yang berterima, ke dalam bahasa sasaran. Adapun retrospektif adalah setelah penerjemah menyelesaikan penerjemahannya, ia membuat komentar terhadap penerjemahannya sendiri dengan merujuk kepada berbagai teori penerjemahan. Adanya komentar dari penerjemah tentang proses penerjemahannya sendiri menandai bahwa ia sudah melakukan sebuah penelitian, yakni penelitian tentang terjemahannya sendiri. Komentar itu mencakup beberapa pembahasan mengenai penerjemahan seperti analisis berbagai aspek di dalam TSu serta pertanggungjawaban mengenai solusi untuk memecahkan berbagai masalah pilihan padanan dalam menerjemahkan. Komentar itu dituangkan dalam bentuk anotasi, yang dapat menguraikan permasalahan pemadanan gramatikal.

\section{Istilah Khusus}

Kata budaya yang pertama saya kategorikan ke dalam istilah khusus. Mengacu pada Nida (lihat Newmark, 1988, hlm. 95), saya menggolongkan istilah khusus ini ke dalam kata budaya yang bersifat kemasyarakatan. Kemasyarakatan di sini maksudnya adalah bahwa kata ini secara khusus terdapat dalam masyarakat bahasa yang bersangkutan.

Lebih lanjut, ada dua kata budaya dan dua frasa yang mengandungi kata budaya yang merupakan istilah khusus yang saya temukan dalam TSu. Frasa ANZAC designs serta kata white-ware dan dairy sangat khas Selandia Baru dan tidak dikenal dalam bahasa Inggris dialek baku/standar. Adapun frasa the rough edge sangat spesifik mengacu pada makna tertentu yang harus dipahami berdasarkan konteksnya dalam paragraf 294.

Tabel 1. Penerjemahan Istilah Khusus dengan Teknik Penerjemahan Deskriptif

\begin{tabular}{cllc}
\hline No. & \multicolumn{1}{c}{ TSu } & \multicolumn{1}{c}{ TSa } & Par. \\
\hline \multirow{3}{*}{1} & $\begin{array}{l}\text { (This week } \\
\text { we're } \\
\text { doing }\end{array}$ & $\begin{array}{l}\text { (Pekan ini kami akan } \\
\text { membuat karangan } \\
\text { bunga untuk Hari } \\
\text { Pahlawan.) }\end{array}$ & [67] \\
\hline
\end{tabular}

\begin{tabular}{|c|c|c|c|}
\hline & $\begin{array}{l}\text { ANZAC } \\
\text { designs.) }\end{array}$ & & \\
\hline 2 & $\begin{array}{l}\text { Our house } \\
\text { was on the } \\
\text { edge of } \\
\text { town. The } \\
\text { rough } \\
\text { edge, some } \\
\text { people } \\
\text { called it. }\end{array}$ & $\begin{array}{l}\text { Rumah kami terletak } \\
\text { di perbatasan kota. } \\
\text { Perbatasan yang } \\
\text { berbahaya, begitu } \\
\text { menurut sebagian } \\
\text { orang, karena di } \\
\text { sana sering terjadi } \\
\text { tindak kekerasan } \\
\text { dan kejahatan. }\end{array}$ & [294] \\
\hline 3 & $\begin{array}{l}\text { Mum } \\
\text { worked } \\
\text { nightshift } \\
\text { at the local } \\
\text { white-ware } \\
\text { factory. }\end{array}$ & $\begin{array}{l}\text { Mama bekerja pada } \\
\text { giliran malam di } \\
\text { sebuah pabrik yang } \\
\text { membuat segala } \\
\text { macam peralatan } \\
\text { dapur yang besar- } \\
\text { besar: kulkas, } \\
\text { kompor, mesin cuci } \\
\text { piring, dan } \\
\text { sebagainya. }\end{array}$ & [298] \\
\hline
\end{tabular}

ANZAC designs, the rough edge, dan white-ware Ketiga istilah ini saya terjemahkan secara penerjemahan deskriptif karena tidak ada padanannya dalam BSa.

Yang pertama adalah ANZAC designs. Istilah ini saya terjemahkan menjadi karangan bunga untuk Hari Pahlawan. Pemadanan ini sesungguhnya mereduksi makna spesifik yang diwakili oleh konsep ANZAC design itu sendiri. Hal ini karena istilah ini sesungguhnya sangat terikat dengan konsep ANZAC dan ANZAC Day.

ANZAC merupakan singkatan (akronim) dari Australian and New Zealand Army Corps, yakni pasukan gabungan Australia dan Selandia Baru. Adapun ANZAC Day adalah semacam Hari Pahlawan dalam budaya sasaran. Definisi ini saya peroleh dari laman nzhistory.net.nz/war/anzacday/introduction (diakses 23 November 2010). Menurut laman ini, ANZAC Day jatuh pada tanggal 25 April, merujuk pada tanggal ketika pasukan gabungan Australia dan Selandia Baru (the ANZACs) mendarat di Semenanjung Galipoli di Turki pada tahun 1915 dalam rangka Gallipoli Campaign, yakni sebuah operasi militer tentara sekutu merebut Selat Dardanela yang menjadi jalur menuju Selat Bosporus dan Laut Hitam (misi ini gagal karena hingga batas waktu yang ditentukan Selat Dardanela tetap berada di bawah kekuasaan Turki). Penetapan tanggal 25 April sebagai "Hari Pahlawan" adalah karena tingginya nilai sejarah yang diwakili oleh tanggal ini. Sebanyak 2.721 orang dari pasukan Selandia Baru gugur dalam 
Gallipoli Campaign tersebut. Jumlah ini adalah seperempat dari seluruh pasukan Selandia Baru yang dikirim ke Galipoli. Oleh karena itu, 25 April senantiasa diperingati setiap tahunnya sebagai "hari mengenang yang gugur di Gallipoli Campaign", yang dalam budaya sasaran sepadan dengan peringatan Hari Pahlawan. Adapun peringatan Hari ANZAC ini selalu diwarnai dengan karangan bunga yang disebut ANZAC designs. Jenis bunganya pun khusus, hanya bunga poppy merah.

Oleh karena keterkaitan yang erat antara konsep ANZAC designs dan konsep ANZAC Day, maka saya memadankannya istilah ini dengan karangan bunga untuk hari Pahlawan, meskipun makna ANZAC designs sesungguhnya lebih spesifik dari itu. Saya memutuskan untuk menghilangkan kata ANZAC karena sukar dilafalkan oleh anak pembaca sasaran yang kemahiran berbahasa Inggrisnya masih terbatas.

Yang kedua adalah istilah the rough edge. Menurut LDOCE (2001, hlm. 1234), rough bermakna "town/area etc $\rightarrow$ a rough area is a place where there is a lot of violence or crime". Kata edge sendiri berkaitan dengan kalimat sebelumnya pada paragraf 294 yakni Our house was on the edge of town, sehingga terjemahannya menjadi perbatasan yang berbahaya, yang kemudian saya deskripsikan dengan frasa karena di sana sering terjadi tindak kekerasan dan kejahatan dengan mengacu pada makna rough berdasarkan kamus di atas.

Selanjutnya adalah white-ware. Menurut laman Wiktionary (diakses 19 Mei 2011) kata whiteware bermakna "any pottery of a white or nearly white colors". Definisi yang lebih lengkap saya peroleh dari Ensiklopedia Britannica daring (diakses 19 Mei 2011), yang menyatakan white-ware sebagai:

"(A)ny of a broad class of ceramic products that are white to off-white in appearance and frequently contain a significant vitreous or glassy, component. Including products as diverse as fine china dinnerware, lavatory sinks and toilets, dental implants, and spark-pug insulators, whitewares all depend for their utility upon a relatively small set of properties: imperviousness to fluids, low conductivity of electricity, chemical inertness, and an ability to be formed into complex shapes. These properties are determined by the mixture of raw materials chosen for the products, as well as by the forming and firing processes employed in their manufacture".
Definisi ini terasa tidak sesuai jika dikaitkan dengan konteks kata oven dalam kalimat sesudahnya (Her job was screwing the handles onto oven doors-par. 298), karena implikatur dari paragraf ini adalah bahwa tokoh mama Barry bekerja di white-ware factory yang memproduksi alat dapur, salah satunya oven (cetak tebal dari saya-pen.). Oleh karena itu saya mencari definisi lain dari white-ware yang sesuai dengan konteks kata oven. Asumsi saya, white-ware dalam bahasa Inggris dialek Selandia Baru adalah sesuatu yang khusus dan tidak sama dengan white-ware menurut kedua definisi di atas. Saya kemudian bertanya pada narasumber saya, Nigel Murphy. Menurutnya, white-ware "...in NZ is basically kitchen appliances such as fridge, stove, freezer, dishwasher and so on. Laundry machines and dryer are included. Also oven. Small stuffs like blender, microwave, etc are not" (disarikan dari komunikasi pribadi, 19 Mei 2011).

Berdasarkan penjelasan di atas, saya menyimpulkan bahwa kata white-ware dalam dialek Selandia Baru memiliki makna khusus yang berbeda dengan makna white-ware secara umum. Akan tetapi ternyata white-ware dalam konteks budaya Selandia Baru tidak memiliki padanan dalam bahasa Indonesia. Oleh karena itu saya memadankannya berdasarkan deskripsi yang diberikan oleh narasumber saya, yakni dengan frasa segala macam peralatan dapur yang besar-besar: kulkas, kompor, mesin cuci piring, dan sejenisnya, sehingga terjemahannya menjadi Mama bekerja pada giliran malam di sebuah pabrik yang membuat segala macam peralatan dapur yang besar-besar: kulkas, kompor, dan sebagainya (cetak tebal dari saya-pen.). Terjemahan ini yang menyebabkan maknanya menjadi lebih umum dan kehilangan nuansa budayanya. Namun hal ini harus dilakukan agar kata ini dapat diterjemahkan dengan wajar dan berterima dalam bahasa anak. Kata whiteware sendiri tidak saya hadirkan dalam terjemahannya untuk menghindari kerancuan dengan kata white-ware dalam definisi umum dalam bahasa Inggris baku.

Tabel 2. Penerjermahan Istilah Khusus dengan Teknik Padanan Budaya

\begin{tabular}{clll}
\hline No. & \multicolumn{1}{c}{ TSu } & \multicolumn{1}{c}{ TSa } & Par. \\
\hline \multirow{4}{*}{4} & $\begin{array}{l}\text { I had some } \\
\text { bus money } \\
\text { saved from }\end{array}$ & $\begin{array}{l}\text { Sebagian uang } \\
\text { ongkos bus }\end{array}$ & sekolah pekan \\
last week and & lalu kutabung, dan & [367] \\
there was a & di perjalanan & \\
dairy on & pulang itu kami & \\
corner. & melewati sebuah & \\
\hline
\end{tabular}


minimarket di

sudut jalan.

\section{Dairy}

Menurut laman Wikipedia (diakses 4 Maret 2011), pengertian umum dairy adalah bangunan tempat memerah susu dari hewan perahan, umumnya sapi atau kambing, guna dikonsumsi manusia. Di beberapa negara terutama di Eropa, dairy juga merupakan tempat memproduksi susu hasil perahan tersebut menjadi mentega, keju, dan yogurt. Hal ini membuat istilah dairy merujuk pada tempat yang memproduksi berbagai produk susu. Makna ini terasa tidak sesuai dengan konteks dairy pada paragraf 367. Untuk itu saya mencari kemungkinan makna lain yang terkandungi dalam kata dairy. Makna ini saya temukan dalam Wikipedia dan Wiktionary.

Menurut Wikipedia (diakses 4 Maret 2011), dalam bahasa Inggris dialek Selandia Baru, dairy merujuk pada "a corner convenience store, or superette". Temuan dalam Wiktionary (diakses 4 Maret 2011) juga berbunyi serupa: dairy adalah "(New Zealand) a corner-store, superette or mini mart of some description".

Untuk memperoleh penjelasan lebih lanjut, saya membuka laman tentang convenience store dan superette. Masih menurut Wikipedia (diakses 4 Maret 2011), convenience store bermakna "small store that may sell items such as sweets, ice-cream, soft drinks, lottery tickets, cigarettes and other tobacco products, newspapers, magazines, along with a selection of processed food and some groceries". Adapun superette adalah "compact food market, convenience store or mini mart" (http://en.wikipedia.org/wiki/Superette, diakses 4 Maret 2011). Istilah superette terdiri dari awalan "super" yang berasal dari kata "supermarket" dan akhiran "ette" yang berarti "smaller version of". Jadi superette berarti "supermarket kecil" atau minimarket.

Berdasarkan definisi ini, saya memadankan dairy dengan minimarket. Namun sebelum itu saya mengecek kebenaran pemahaman saya pada narasumber saya, Nigel Murphy. Ada dua hal yang saya konfirmasi: (i) apakah benar dairy adalah sejenis toko swalayan kecil, dan (ii) apakah dairy menjual kue pai sebagaimana yang disampaikan dalam TSu. Murphy menjawab kedua pertanyaan saya itu dengan mendefinisikan dairy sebagai "a small local store that sells milk, bread, pie and all sorts of daily necessities, and it's like a self-service store" (komunikasi pribadi via surel, 5 Maret 2011). Dengan demikian saya menyimpulkan bahwa benar dairy adalah minimarket. Teknik penerjemahan yang saya gunakan adalah padanan budaya. Adapun kata dairy-nya sengaja tidak saya hadirkan dalam terjemahannya agar tidak terjadi kerancuan dengan istilah dairy dalam pengertian umumnya dalam bahasa Inggris standar.

\section{Nama Diri}

Kata budaya lain adalah nama diri. Oleh Nida (lihat Newmark, 1988, hlm. 95), nama diri semacam ini digolongkan ke dalam nama organisasi, adatistiadat, aktivitas, konsep, dll. Nama diri menurut Keraf (2001, hlm. 90) adalah istilah yang paling khusus, sehingga ketika digunakan tidak akan menimbulkan salah paham. Ada dua buah nama diri yang saya anotasi. Teknik penerjemahan yang saya gunakan adalah pemadanan dengan keterangan tambahan.

Tabel 3. Penerjemahan Nama Diri dengan Teknik Pemadanan dengan Keterangan Tambahan

\begin{tabular}{|c|c|c|c|}
\hline No. & $\mathrm{TSu}$ & $\mathrm{TSa}$ & Par. \\
\hline 5 & $\begin{array}{l}\text { And extra- } \\
\text { curricular } \\
\text { educational } \\
\text { experiences are } \\
\text { what I do after } \\
\text { school. Like } \\
\text { tennis, clarinet, } \\
\text { swimming, } \\
\text { Boys' Brigade } \\
\text { and floral art (to } \\
\text { nurture my } \\
\text { creative side). }\end{array}$ & $\begin{array}{l}\text { Sedangkan } \\
\text { kegiatan } \\
\text { ekstrakurikuler } \\
\text { yang mendidik } \\
\text { adalah kegiatan } \\
\text { yang kulakukan } \\
\text { sepulang } \\
\text { sekolah, seperti } \\
\text { latihan tenis, } \\
\text { klarinet, renang, } \\
\text { kegiatan } \\
\text { kepanduan } \\
\text { Boys' Brigade, } \\
\text { dan kursus } \\
\text { merangkai bunga } \\
\text { (untuk } \\
\text { mengembangkan } \\
\text { sisi kreatifku). }\end{array}$ & [17] \\
\hline 6 & $\begin{array}{l}\text { It's like a scene } \\
\text { from } \\
\text { 'Crimewatch'. }\end{array}$ & $\begin{array}{l}\text { Seperti adegan } \\
\text { dalam acara } \\
\text { televisi } \\
\text { "Crimewatch" } \\
\text { saja. }\end{array}$ & {$[170]$} \\
\hline
\end{tabular}

Boys' Brigade.

Karena merupakan istilah khusus yang merujuk kepada nama sebuah organisasi, maka frasa Boys' Brigade tidak diterjemahkan. Guna membantu pembaca memahami nama diri tersebut, informasi tertentu harus ditambahkan, yakni kegiatan kepanduan. Frasa ini dipilih karena Boys' Brigade merupakan sebuah organisasi kepemudaan yang 
memiliki aktivitas perkemahan, baris-berbaris, halang-rintang, dll yang serupa dengan kegiatan kepanduan. Yang membedakan Boys' Brigade dengan kegiatan kepanduan biasa adalah penanaman nilai-nilai Kristen di dalam setiap aktivitasnya. Hal ini karena Boys Brigade memang merupakan kegiatan kepanduan yang berafiliasi pada agama Kristen.

Dalam terjemahannya, afiliasi ini dirasa tidak perlu ditampilkan karena secara keseluruhan novel ini bukan merupakan novel yang mengisahkan kehidupan keagamaan tokohnya. Peniadaan keterangan yang menunjukkan afiliasi keagamaan ini membuat terjemahannya menjadi lebih netral dan sesuai dengan budaya sasaran yang mayoritas Muslim.

Meskipun terjemahan dibuat netral, saya merasa perlu memberi penjelasan lebih lanjut tentang organisasi ini. Boys' Brigade didirikan oleh William Alexander Smith pada 4 Oktober 1883 di Free Church Mission Hall, Glasgow, Skotlandia. Tokoh ini adalah seorang anggota militer paruhwaktu (lihat http://www.bb.org.nz/about/, diakses 11 Januari 2011) yang mengajar kelas siswa lelaki di Sekolah Minggu di gereja tersebut.

Pendirian Boys' Brigade awalnya merupakan bentuk kekhawatiran Smith atas tiadanya disiplin di kalangan siswa Sekolah Minggunya. Ia mengalami kesulitan untuk mengajarkan mata pelajaran utama yang diampunya yakni nilai-nilai Kristianitas karena terlalu sibuk menenangkan kelasnya yang luar biasa berisik dan tidak tertib. Untuk mengatasi masalah ini, ia menerapkan penggemblengan ala militer terhadap siswa-siswanya melalui kegiatan baris-berbaris dan penguasaan senjata (lihat http://www.bb.org.nz/about/, diakses 11 Januari 2011). Lebih lanjut, ia melatih anak-anak itu dengan sangat keras dan memberi anak-anak itu seragam layaknya militer. Pelatihan ala militer dan pengenaan seragam di kalangan anggotanya yang merupakan anak-anak membuat Boys Brigade serupa dengan kegiatan kepanduan di budaya sasaran. Lebih lanjut, pemberian seragam membuat Boys Brigade menjadi organisasi kepemudaan berseragam pertama di dunia (http://sabdaspace.org/boys_brigade, diakses 11 Januari 2010). Kegiatan penggemblengan ala Boys' Brigade ini menuai hasil karena selanjutnya siswasiswa di kelas tersebut menjadi sangat disiplin dan tertib.
Boys' Brigade memiliki moto "sure and steadfast" atau "kuat dan aman" yang diambil dari Ibrani 6:19. Moto ini mengacu kepada keyakinan bahwa Kristus adalah jangkar (anchor) yang kuat dan aman bagi jiwa manusia (http://sabdaspace.org/boys_brigade, diakses 11 Januari 2010). Keyakinan bahwa Kristus adalah "jangkar" inilah yang kemudian mendasari gambar jangkar menjadi lambang organisasi ini.

Tujuan Boys' Brigade adalah membangun "true Christian manliness" (kelelakian Kristen yang sesungguhnya). Landasan dari nilai ini adalah keyakinan bahwa lelaki dan perempuan diciptakan berbeda sehingga, dengan berpegang pada nilainilai Kristianitas, di dalam jiwa setiap lelaki Kristen harus terbangun kelelakian yang sesungguhnya, sebagaimana juga di dalam jiwa perempuan Kristen harus terbangun keperempuanan yang sesungguhnya. Menurut Miller, "true Christian manliness" didirikan dengan berdasarkan nilai-nilai kebenaran (truth), kejujuran (honesty), keadilan (justice), kesucian (purity), keindahan (beauty), dan cinta (love), yang harus ditanamkan sejak masa kanak-kanak (boyhood) karena jika tidak maka anak lelaki itu tidak akan tumbuh sebagai lelaki Kristen yang sesungguhnya (http://www.gracegems.org/Miller/

Christian_manliness.htm, diakses 11 Januari 2010).

\section{'Crimewatch'.}

Istilah ini adalah nama diri yang merujuk pada acara televisi. Crimewatch adalah sejenis program faktual yang menayangkan rekonstruksi kasus-kasus tindak pidana yang paling menyita perhatian publik di Inggris Raya (lihat http://www.bbc.co.uk/crimewatch/aboutcrimewatc h/about_the_show.html, diakses 5 Januari 2011). Agaknya acara ini juga ditayangkan di televisi Selandia Baru. Saya menerjemahkannya dengan memberi kata-kata khusus (classifier) berupa frasa acara televisi sehingga terjemahannya menjadi acara televisi "Crimewatch".

\section{Hewan}

Kata budaya selanjutnya adalah hewan. Oleh Nida (lihat Newmark, 1988, hlm. 95) hewan digolongkan pada kategori ekologi. Ada dua jenis hewan yang menarik untuk dianotasi. Jenis pertama adalah anjing, yang terdiri dari tiga subjenis: pug, sausage, dan staffy. Jenis hewan kedua adalah guinea pig, sejenis marmot. Teknik penerjemahan yang saya gunakan adalah kuplet. 
Tabel 4. Penerjemahan Nama Hewan dengan Teknik Kuplet

\begin{tabular}{ll}
\hline No. TSu & \multicolumn{1}{c}{ TSa } \\
\hline & Bob menyebutnya \\
& Bitsa karena anjing \\
& itu memang tidak \\
& jelas jenisnya. \\
& Sekilas dia mirip \\
& jenis anjing \\
& tertentu, tapi juga \\
& mirip jenis anjing \\
Bob calls him & lain. Bitsa memang \\
Bitsa & plesetan dari bits \\
because he's & of, yang artinya \\
got bits of & "mirip-mirip". Dia \\
everything in & gemuk, berbulu \\
him. Bits of & pendek, bermuka \\
pug, bits of & rata, dan \\
sausage, bits & berhidung pesek, \\
of staffy. & mirip anjing pug. \\
Bitsa & Juga berkaki \\
everything! & pendek tapi \\
& bertubuh panjang, \\
& mirip anjing tekel. \\
& Tapi sekaligus \\
& kekar dan sangar \\
& seperti anjing \\
& staffy bull terrier. \\
& Mirip-mirip dengan \\
& semuanya! \\
\hline
\end{tabular}

Masalah no. 7 memiliki kategori yang sama, yakni menerjemahkan jenis anjing. Ada tiga spesies anjing yang disebutkan di atas, yakni pug, sausage, dan staffy.

\section{a. Pug}

Berdasarkan penelusuran dokumen daring, saya mendapati anjing pug sebagai anjing ras jenis anjing toy atau anjing berukuran mungil, namun dengan ukuran terbesar di kelasnya, karena rata-rata anjing toy memiliki bobot di bawah $6 \mathrm{~kg}$ sementara bobot anjing pug bisa mencapai $8 \mathrm{~kg}$ (lihat http://id.wikipedia.org/wiki/pug dan Sant, dalam http://www.anjingkita.com/wmview.php?ArtID=3 669, diakses 7 Februari 2011). Adapun menurut laman http://en.wikipedia.org/wiki/pug, anjing pug adalah "a 'toy' (very small) breed of dog with a wrinkly, short-muzzled face, and curled tail".

Kata pug berasal dari bahasa Latin pugnus yang artinya "kepalan tangan" (http://id.wikipedia.org/wiki/pug, diakses 7 Februari 2011), karena wajahnya hanya selebar kepalan tangan. Dalam BSa, pug disebut anjing pug, sehingga terjemahannya menggunakan teknik transferensi yang dipadukan dengan penerjemahan deskriptif, yakni dengan mendeskripsikan anjing jenis ini berdasarkan berbagai deskripsi di atas sehingga terjemahannya menjadi Dia gemuk, berbulu pendek, bermuka rata, dan berhidung pesek, mirip anjing pug. Karena menggunakan dua teknik sekaligus, maka penerjemahannya merupakan kuplet.

\section{b. Sausage dan staffy}

Dalam menerjemahkan jenis kedua anjing ini, saya menggunakan teknik kuplet yang merupakan kombinasi dari padanan budaya dan penerjemahan deskriptif.

Yang pertama adalah sausage. Anjing sausage adalah julukan bagi anjing trah jenis dachshund atau teckel asal Jerman. Disebut demikian karena tubuhnya panjang menyerupai sosis, sementara kakinya pendek, tidak seimbang dengan panjang tubuhnya. Kata dachshund sendiri berasal dari bahasa Jerman der Dasch (berang-berang) dan der Hund (anjing), karena ukuran standar anjing jenis ini memang dikembangbiakkan untuk mengendus, mengejar, dan berburu berang-berang dan hewan lain yang tinggal di lubang di dalam tanah, sementara ukuran mininya digunakan untuk berburu kelinci (http://id.wikipedia.org/wiki/dachshund, diakses 23 Januari 2011).

Saya menerjemahkannya menjadi anjing tekel karena demikianlah anjing ini dikenal di Indonesia. Nama tekel ini terpengaruh oleh bahasa Belanda (lihat http://id.wikipedia.org/wiki/dachshund, diakses 23 Januari 2011). Deskripsinya saya ungkapkan dalam bentuk frasa Juga berkaki pendek tapi bertubuh panjang, sesuai dengan definisi yang saya peroleh dari penelusuran dokumen.

Yang kedua adalah staffy. Anjing jenis ini bernama resmi the staffordshire bull terrier. Nama julukannya selain staffy adalah staffie, stafford, staffross, atau staff. Anjing jenis ini adalah anjing trah berukuran sedang, berbulu pendek, dan awalnya dikembangbiakkan sebagai anjing petarung. Penampilan fisik staffy berotot dan tampak mengancam (intimidating). Namun anjing jenis ini tidak cocok dilatih sebagai anjing penjaga karena karakter alaminya yang penyayang terhadap manusia (lihat http://en.wikipedia.org/wiki/staffordshire_bull_terr ier).

Menurut laman http://id.88db.com/HewanPeliharaan/Jual-Beli-Hewan/ad.241925 (diakses 21 
Februari 2011), di Indonesia staffy dikenal dengan nama staffy bull terrier, bukan staffy saja. Oleh karena itu saya menyimpulkan bahwa staffy bull terrier adalah padanan budaya dari staffy, walaupun nama ini tetap mengandung unsur transferensi, sehingga saya menerjemahkannya menjadi anjing staffy bull terrier dengan diberi deskripsi berupa frasa Tapi sekaligus kekar dan sangar sebagaimana definisi yang disebutkan di atas.

Tabel 5. Penerjemahan Nama Hewan dengan Teknik Kuplet

\begin{tabular}{|c|c|c|c|}
\hline No. & $\mathrm{TSu}$ & $\mathrm{TSa}$ & Par. \\
\hline 8 & $\begin{array}{l}\text { On one } \\
\text { side was a } \\
\text { fluffy grey } \\
\text { kitten and } \\
\text { on the } \\
\text { other a } \\
\text { bunch of } \\
\text { guinea } \\
\text { pigs. }\end{array}$ & $\begin{array}{l}\text { Di sebelahnya ada } \\
\text { seekor kucing abu- } \\
\text { abu berbulu lembut, } \\
\text { sedangkan di } \\
\text { sebelah satunya ada } \\
\text { sekelompok guinea } \\
\text { pig, hewan mungil } \\
\text { sejenis marmot, } \\
\text { tapi ukurannya } \\
\text { lebih kecil. }\end{array}$ & [271] \\
\hline
\end{tabular}

\section{Guinea pig}

Menurut

laman

http://en.wikipedia.org/wiki/guinea_pig (diakses 21 Maret 2011), guinea pig (Cavia porcellus) atau disebut juga cavy, adalah sejenis hewan pengerat dengan famili Caviidae dan genus Cavia. Hewan ini sama sekali tidak termasuk keluarga babi, walaupun namanya mengandung kata pig. Melekatnya kata pig pada nama hewan ini mungkin berasal dari nama ilmiahnya porcellus yang dalam bahasa Latin berarti "little pig". Disebut demikian karena hewan ini sedikit-banyak mirip dengan babi: ukuran kepalanya relatif besar untuk ukuran tubuhnya, lehernya bulat-pendek, nyaris tidak berekor, suaranya menguik seperti babi, dan banyak makan.

Lebih lanjut, hewan ini juga bukan berasal dari Guinea, melainkan dari Pegunungan Andes di Amerika Selatan. Nama guinea diduga melekat pada hewan ini lantaran hewan ini bukan hewan asli Eropa. Pada masa itu orang Eropa menyebut negerinegeri jauh yang tak dikenal dengan sebutan Guinea, sehingga hewan yang berasal dari "negeri jauh yang tidak dikenal" ini pun disebut guinea pig.
Dahulu hewan ini memainkan peran penting dalam masyarakat asli Amerika Selatan, yakni sebagai bahan pangan, bahan dasar obat-obatan, dan digunakan sebagai sesajen dalam upacara keagamaan.

Masih menurut laman yang sama, di masyarakat Barat dewasa ini, guinea pig dikembangbiakkan sebagai hewan peliharaan karena sifat alamiahnya yang penurut dan mudah dirawat. Adalah para pedagang Spanyol, Belanda, dan Inggris yang membawanya dari benua Amerika ke Eropa. Di Indonesia, hewan ini dibawa oleh penjajah Belanda sehingga di sini hewan jenis ini dikenal dengan nama tikus Belanda (lihat http://id.wikipedia.org/wiki/tikus_belanda, diakses 21 Maret 2011). Meskipun demikian, saya tidak menerjemahkannya dengan tikus Belanda karena istilah ini benar-benar asing dalam budaya sasaran, terutama dalam bahasa anak. Apalagi dalam budaya sasaran guinea pig tidak menjadi hewan peliharan seperti halnya hewan sejenis yakni hamster. Ini berarti dalam budaya sasaran guinea pig merupakan jenis hewan yang asing, sehingga dalam TSa nuansa asingnya harus dipertahankan, sehingga kemudian saya memutuskan untuk mempertahankan istilah aslinya dengan memberikan deskripsi berupa frasa hewan mungil sejenis marmot, tapi ukurannya lebih kecil. Saya menggunakan hewan marmot sebagai acuan karena menurut laman http://id.wikipedia.org/wiki/tikus_belanda (diakses 21 Maret 2011), tikus belanda atau guinea pig ini kerap salah disebut sebagai marmot, hewan sesama jenis pengerat namun ukurannya lebih besar. Deksripsi ini menunjukkan bahwa guinea pig lebih kecil dari marmot, sehingga saya memberi deskripsi berupa frasa ukurannya lebih kecil dalam terjemahannya. Dengan demikian teknik yang saya gunakan adalah kuplet yakni kombinasi antara tranferensi dan penerjemahan deskriptif.

\section{Makanan}

Kata budaya berikutnya adalah makanan. Oleh Nida (lihat Newmark, 1988, hlm. 95) makanan digolongkan pada kategori artefak atau materi. Ada tiga nama makanan yang saya anotasi. Penerjemahannya menggunakan teknik pemadanan dengan keterangan tambahan, transferensi, dan penerjemahan fonologis. 
Tabel 6. Penerjemahan Nama Makanan dengan Teknik Pemadanan dengan Keterangan Tambahan

\begin{tabular}{|c|c|c|c|}
\hline No. & $\mathrm{TSu}$ & $\mathrm{TSa}$ & Par. \\
\hline 9 & $\begin{array}{l}\text { 'Who } \\
\text { dropped } \\
\text { that?' } \\
\text { demands } \\
\text { Miss P, } \\
\text { scooping up } \\
\text { a dropped } \\
\text { muesli bar } \\
\text { wrapper. }\end{array}$ & $\begin{array}{l}\text { "Siapa yang } \\
\text { membuang ini } \\
\text { sembarangan?" } \\
\text { tanya Bu Guru } \\
\text { Pringles sambil } \\
\text { memungut bungkus } \\
\text { muesli batangan } \\
\text { yang tergeletak } \\
\text { begitu saja di lantai. } \\
\text { (Kalau kamu } \\
\text { belum tahu, muesli } \\
\text { batangan itu } \\
\text { semacam sereal } \\
\text { yang dipadatkan. } \\
\text { Bentuknya persegi } \\
\text { panjang mirip } \\
\text { wafer.) }\end{array}$ & [111] \\
\hline
\end{tabular}

\section{Muesli bar}

Menurut LDOCE (2001, hlm. 936), muesli adalah "grains, nuts, and dried fruit, mixed together and eaten with milk as a breakfast food". Adapun menurut OALD (1995, hlm. 763), muesli adalah "a mixture of cereal, nuts, and dried fruit, usu eaten with milk at breakfast". Dalam BSa, jenis makanan semacam ini dikenal sebagai sereal. Akan tetapi muesli memiliki kekhasan yang tidak terdapat pada sereal biasa, yakni rasa manisnya hanya mengandalkan rasa manis alami dari buah-buahan yang terkandungi di dalamnya, atau dengan kata lain hanya mengandungi fruktosa. Ini berarti muesli bersifat rendah sukrosa sehingga baik untuk diet. Kecuali itu unsur kacang yang terdapat di dalamnya membuat muesli juga tinggi protein, tidak seperti sereal pada umumnya (lihat Wisegeek.com, diakses 26 Februari 2011).

Dikaitkan dengan istilah muesli bar, penjelasannya adalah sebagai berikut: muesli bar menurut Thefreedictionary.com (diakses 23 Januari 2011) adalah "(cookery) a snack made of compressed muesli ingredients". Berdasarkan penjelasan ini, saya menyimpulkan bahwa muesli bar merupakan jenis muesli yang sangat khas, yaitu yang berbentuk compressed (dipadatkan). Ini berarti muesli ada pula yang berbentuk tidak padat, sebagaimana sereal yang biasa dikenal di budaya sasaran. Oleh karena itu, kata bar-nya harus saya hadirkan di sini, yang saya terjemahkan menjadi batangan, sehingga terjemahannya menjadi muesli batangan. Penghadiran kata batangan ini saya anggap wajar dan berterima, karena kita juga menerjemahkan, misalnya, istilah chocolate bar dengan cokelat batangan.

Berkenaan dengan kata muesli, saya memutuskan untuk tidak menerjemahkannya, mengingat nuansa asingnya sangat kuat. Penganan ini memang sudah tersedia di Indonesia, namun belum memasyarakat. Muesli bar hanya dapat ditemui di hipermarket di kota-kota besar yang tidak terjangkau oleh sebagian besar masyarakat budaya sasaran.

Dari hasil survei skala kecil, saya menemukan sejenis sereal yang berbentuk padat sebagaimana yang dimaksud oleh penulis TSu. Jenis sereal macam ini disebut "biskuit sereal". Penganan ini sudah agak dikenal dalam budaya sasaran, terutama di perkotaan. Akan tetapi bentuknya tidak batangan sebagaimana muesli bar, melainkan bundar pipih seperti biskuit. Citra ini tidak sesuai dengan citra muesli bar. Oleh karena itu, dalam terjemahannya, saya memutuskan untuk mendeskripsikan muesli bar dalam terjemahannya dengan penghadiran frasa muesli batangan itu semacam sereal yang dipadatkan. Frasa sereal yang dipadatkan ini penting untuk disampaikan agar pembaca sasaran dapat memahami apa yang dimaksud dengan muesli batangan. Untuk melengkapi pemahaman pembaca, saya juga menambahkan gambaran bentuk muesli bar dengan kalimat Bentuknya persegi panjang mirip wafer. Diharapkan, dengan penghadiran kata wafer, pembaca sasaran dapat lebih memahami membayangkan bentuk muesli bar, sehingga konsep yang diwakili oleh istilah ini dapat terasa wajar dan berterima. Pemadanan semacam ini menggunakan teknik pemadanan dengan keterangan tambahan.

Tabel 7. Penerjemahan Nama Makanan dengan Teknik Transferensi

\begin{tabular}{cllc}
\hline No. & \multicolumn{1}{c}{ TSu } & \multicolumn{1}{c}{ TSa } & Par \\
\hline \multirow{2}{*}{$\begin{array}{l}\text { I eat four } \\
\text { chickpea } \\
\text { rissoles } \\
\text { and tomato } \\
\text { salad like } \\
\text { nothing } \\
\text { happened. }\end{array}$} & $\begin{array}{l}\text { Aku makan empat } \\
\text { potong risoles } \\
\text { chickpea } \text { dan salad } \\
\text { tomat seolah tak } \\
\text { terjadi apa pun. }\end{array}$ & [167] \\
\hline
\end{tabular}

\section{Chickpea rissole}

Kata chickpea dalam LDOCE (2001, hlm. 219) berarti "a large brown pea which is cooked and eaten". Kata pea sendiri bermakna "a large round green seed that is cooked and eaten as vegetable". 
Saya memadankan rissole dengan risoles. Dalam budaya sasaran, penganan risoles cukup dikenal, walaupun risoles dalam budaya sasaran agak berbeda dengan rissole yang dimaksud dalam TSu. Menurut laman Wikipedia (diakses 10 Mei 2011), di Indonesia, risoles adalah penganan berisi daging, biasanya daging cincang, bihun, dan sayuran. Isi ini dibungkus dadar dan digoreng dengan minyak yang banyak (deep fried) setelah dilapisi tepung panir dan kocokan telur ayam. Di Selandia Baru, rissole tidak memakai lapisan luar dari tepung panir melainkan dari remah-remah roti. Isinya biasanya daging cincang dan bawang Bombay, dan dihidangkan pada acara barbekyu pada musim panas (lihat http://en.wikipedia.org/wiki/rissole, diakses 10 Mei 2011). Rissole ala Selandia Baru serupa dengan rissole ala Australia - digoreng dengan sedikit minyak (pan fry) (lihat http://en.wikipedia.org/wiki/rissole, diakses $10 \mathrm{Mei}$ 2011, dan Webster's Online Dictionary, diakses 26 Februari 2011). Dari penjelasan ini tampak perbedaan antara risoles (BSa) dan rissole (BSu). Namun saya tetap memadankan rissole dengan risoles dengan pertimbangan bahwa risoles sudah dikenal dalam budaya sasaran sehingga penganan apa yang dimaksud oleh penulis TSu dengan kata rissole dapat dimengerti oleh pembaca sasaran.

Lebih lanjut, dalam TSa, dinyatakan bahwa risolesnya berisi chickpea. Di dalam dua buah kamus dwibahasa Inggris-Indonesia yang saya acu, kata chickpea bermakna "kacang buncis". Tapi ketika saya mengecek di Kamus Indonesia-Inggris: An Indonesian-English Dictionary (1992, hlm. 95), kata buncis bermakna "stringbean" dan bukan "chickpea". Dengan demikian saya menyimpulkan bahwa chickpea bukanlah buncis melainkan sejenis buncis yang tidak dikenal dalam BSa. Oleh karena itu, saya memutuskan untuk tidak menerjemahkannya melainkan meminjam saja kata chickpea tersebut, sehingga terjemahan chickpea rissole menjadi risoles chickpea. Hal ini bertujuan untuk mempertahankan nuansa asing di dalam TSa. Teknik yang saya gunakan adalah transferensi dengan fokus pada kata chickpea, mengingat kata rissole sudah ada padanannya dalam $\mathrm{BSa}$.
Tabel 8. Penerjemahan Nama Makanan dengan Teknik Penerjemahan Fonologis

\begin{tabular}{|c|c|c|c|}
\hline No. & $\mathrm{TSu}$ & $\mathrm{TSa}$ & Par. \\
\hline & By day three & & \\
\hline 11 & $\begin{array}{l}\text { Mum was } \\
\text { sneaking him } \\
\text { sausage } \\
\text { casserole, } \\
\text { and by the } \\
\text { end of the } \\
\text { week he has } \\
\text { his own dog } \\
\text { bowl and } \\
\text { everything. }\end{array}$ & $\begin{array}{l}\text { Pada hari ketiga } \\
\text { diam-diam Mama } \\
\text { memberi Bitsa } \\
\text { kaserol sosis, dan } \\
\text { pada akhir pekan } \\
\text { itu Bitsa pun sudah } \\
\text { punya mangkuk } \\
\text { makan sendiri. }\end{array}$ & {$[320]$} \\
\hline
\end{tabular}

Sausage casserole

Teknik penerjemahan fonologis saya gunakan untuk menerjemahkan sausaege casserole.

Kata sausage menurut LDOCE (2001, hlm. 1266) adalah "a small tube of skin filled with a mixture of meat, spices etc, eaten hot or cold". Dalam BSa, padanannya adalah sosis. Dalam KBBI (2008, hlm. 1498), kata sosis memiliki dua makna: " $n 1$ bentuk silinder panjang; 2 daging cincang yg dibumbui dikemas dl selaput sehingga berbentuk silinder panjang”. Sosis dalam konteks makanan adalah definisi yang kedua, yang maknanya kurang-lebih sama dengan makna sausage dalam LDOCE.

Masih menurut LDOCE (2001, hlm. 195), kata casserole ( $\mathrm{n}$ ) bermakna " 1 food that is cooked slowly in liquid in a covered dish in the oven; 2 a deep covered dish used for cooking food in the oven". Dalam konteks ini, kata casserole mengacu pada makna pertama. Dalam Kamus InggrisIndonesia: An English-Indonesia Dictionary (1998, hlm. 101) kata casserole (kb) bermakna "1 tempat makanan yg ada tutupnya utk memasak atau menyajikan makanan; 2 makanan biasanya merupakan sebuah adukan dimasak didlm kuah di tempat sm itu". Makna yang kedua serupa dengan makna casserole dalam LDOCE. 
Saya memadankan casserole dengan kaserol sesuai dengan bunyi/lafalnya dalam BSa. Kata kaserol (n) sendiri dalam KBBI hanya merujuk pada satu makna dalam laras kimia, yakni "cawan tembikar dng pegangan, yg digunakan dl laboratorium" (2008, hlm. 690). Makna ini tidak sesuai dengan konteks paragraf 320, karena casserole di sini adalah sejenis makanan. Adapun definisi kaserol yang sesuai dengan konteks paragraf ini saya peroleh dari http://saossambal.blogspot.com/2008/04/kaserolroti.html (diakses 10 Mei 2011), yakni 'makanan yang terdiri dari berbagai jenis bahan yang dicampur-campur kemudian dipanggang'. Definisi ini saya anggap cukup mewakili makna casserole yang dimaksud dalam paragraf 320, yakni makanan yang dimasak dengan cara ditaruh di dalam semacam pinggan lalu dipanggang di dalam oven. Pemadanan casserole dengan kaserol juga bertujuan untuk tetap menghadirkan nuansa asing dalam terjemahannya, meskipun secara grafologis kata ini telah bersesuaian dengan tata ejaan BSa.

\section{Tanaman}

Jenis kata budaya yang terakhir adalah tanaman. Sebagaimana juga hewan, oleh Nida (lihat Newmark, 1988, hlm. 95) tanaman digolongkan pada kategori ekologi.

Tabel 9. Penerjemahan Jenis Tanaman dengan Teknik Pemadanan dengan Keterangan Tambahan

\begin{tabular}{cclc}
\hline No. & \multicolumn{1}{c}{ TSu } & \multicolumn{1}{c}{ TSa } & Par. \\
\hline \multirow{3}{*}{12} & $\begin{array}{l}\text { 'Wha-' I } \\
\text { drop the bunch } \\
\text { of red poppies } \\
\text { I'm holding in } \\
\text { fright. }\end{array}$ & $\begin{array}{l}\text { sangat terkejut, } \\
\text { hingga } \\
\text { menjatuhkan } \\
\text { rangkaian bunga } \\
\text { poppy merah } \\
\text { yang kubawa. }\end{array}$ & [67] \\
\hline
\end{tabular}

\section{Red poppy}

Menurut laman Wikipedia (diakses tanggal 23 November 2010), poppy adalah kelompok tanaman berbunga (flowering plant) yang merupakan anggota famili poppy. Umumnya, poppy tumbuh di kebun. Varian warnanya cukup beraneka, sementara kelopaknya terdiri dari 4-6 helai.

Bangsa Yunani-Romawi kuno mengenal poppy sebagai simbol "tidur" dan "kematian". Melambangkan "tidur" karena salah satu spesies poppy yakni Papaver somniferum dapat diekstraksikan sebagai zat psikotropika yang dikenal sebagai opium, yang menimbulkan efek mengantuk/tidur. Sementara itu, poppy juga melambangkan "kematian" karena spesies pорру terbanyak adalah yang berwarna merah yang merupakan warna darah. Poppy juga digunakan sebagai simbol "kebangkitan kembali setelah kematian dalam peperangan". Adapun spesies yang melambangkan hal ini adalah corn poppy (Papaver rhoeas) berwarna merah scarlet.

Adalah Moina Michael (1869-1944), seorang pegawai kantin YMCA di New York, yang mempopulerkan poppy sebagai "symbol of remembrance". Ia tertarik untuk menjadikan poppy sebagai simbol "mengenang yang gugur di medan laga" setelah membaca puisi karya Letkol John McCrae, seorang prajurit divisi medis dari pasukan Kanada, berjudul "In Flanders Field". Puisi yang sesungguhnya didedikasikan McCrae untuk rekannya yang tewas di dalam Pertempuran Kedua di Ypres, salah satu desa kecil di West Flanders di Belgia, Letnan Alexis Helmer, telah menginsiprasi Moina, sehingga bersama rekannya, Madame E. Guerin, ia menjadikan poppy terkenal di AS sebagai simbol "mengenang yang gugur di medan laga" (lihat www.nzhistory.net.nz/war/anzacday/poppies, diakses 23 November 2010)

Di Selandia Baru, poppy merah yang dikenal juga dengan nama flanders poppy. Jenis inilah yang digunakan sebagai dekorasi dalam peringatan ANZAC Day. Disebut flanders poppy karena tanaman ini merupakan tanaman yang banyak tumbuh di wilayah West Flanders, tempat ribuan prajurit Selandia Baru sebagai bagian dari pasukan sekutu gugur pada Perang Dunia I (lihat www.nzembassy.com/belgium/relationshipbetween-new-zealand-and-belgium/new-zealandand-belgium/war-commemorations-bel-1, diakses 17 Februari 2011). Oleh karenanya, desain karangan bunga untuk ANZAC Day menggunakan bunga poppy merah.

Berkaitan dengan masalah di atas, saya memutuskan untuk memadankan red poppy dengan bunga poppy merah. Kata bunga saya pilih untuk menjelaskan kata poppy, yakni bahwa poppy adalah sejenis bunga dan bukan tanaman lain. Teknik penerjemahan yang saya gunakan dalam pemadanan ini adalah pemadanan dengan keterangan tambahan. Adapun kata poppy tidak saya terjemahkan karena nuansa asingnya harus terasa, mengingat konteks bunga poppy di sini adalah sebagai simbol untuk mengenang pahlawan perang, yang hanya dikenal di budaya sumber. 


\section{Ungkapan Khusus}

Saya mengategorikan ketiga istilah ini ke dalam ungkapan khusus karena ketiganya berada dalam konteks penjulukan terhadap sesuatu/seseorang yang bernuansa merendahkan/mengejek.

Tabel 10. Penerjemahan Ungkapan Khusus dengan Teknik Modulasi

\begin{tabular}{cccc}
\hline No. & \multicolumn{1}{c}{ TSu } & \multicolumn{1}{c}{ Tsa } & Par. \\
\hline 13 & $\begin{array}{l}\text { 'You're such } \\
\text { a tittle-tattle, } \\
\text { Timothy.' }\end{array}$ & $\begin{array}{l}\text { "Kamu memang } \\
\text { benar-benar tukang } \\
\text { ngadu, Timothy." }\end{array}$ & {$[8]$} \\
\hline
\end{tabular}

\section{Tittle-tattle}

Kata tittle-tattle dalam LDOCE (2001, hlm. 1519) bermakna "unimportant conversation about other people and what they are doing; gossip". Makna tersebut terasa kurang berterima jika dikaitkan dengan konteks cerita yang berkisah tentang seorang anak bernama Timothy yang suka mengadu. Dengan kata lain, tittle-tattle harus diposisikan dalam konteks keseluruhan cerita, yakni tentang Timothy yang gemar mengadu, sehingga makna kontekstual tittle-tattle di sini adalah pengadu. Kata pengadu dalam KBBI (2008, hlm. 14) bermakna " $n 1$ orang yang suka mengadu; 2 orang yang mengadukan". Makna ini sesuai dengan makna kontekstual tittle-tattle di sini. Adapaun teknik yang digunakan ketika memadankan tittle-tattle dengan pengadu adalah modulasi, karena di sini terjadi perubahan cakupan makna referensial demi kesesuaian dengan makna kontekstual paragraf tersebut. Untuk menjustifikasi perubahan cakupan ini, saya mencari kemungkinan makna lain yang terdapat dalam kata tittle-tattle. Makna tersebut saya peroleh dalam TCMD (1982, hlm. 1361), yang menyatakan tittle-tattle (n) sebagai "(1) gossip; telltale (2) to reveal private or confidential matters in idle gossip; act as a tale bearer". Definisi kedua dalam kamus ini, yakni "act as a tale bearer", ternyata sepadan dengan makna kontekstual tittle-tattle di sini.

Selanjutnya, kata pengadu sendiri masih terasa kaku untuk laras dan ragam bahasa anak. Saya mengganti pengadu dengan frasa tukang ngadu yang dalam BSa terasa lebih berterima dan dapat dipahami oleh pembaca sasaran, dalam hal ini anakanak. Pemilihan frasa tukang ngadu ini bertujuan untuk memberikan terjemahan yang wajar dan berterima sesuai situasi karena keberadaannya adalah di dalam kalimat yang merupakan percakapan informal.
Tabel 11. Penerjemahan Ungkapan Khusus dengan Teknik Padanan Fungsional

\begin{tabular}{crlr}
\hline No. & TSu & \multicolumn{1}{c}{ TSa } & Par. \\
\hline 14 & $\begin{array}{l}\text { What a } \\
\text { honker! }\end{array}$ & $\begin{array}{l}\text { Wah, } \\
\text { hidungnya } \\
\text { besar sekali! }\end{array}$ & {$[360]$} \\
\hline
\end{tabular}

What a honker!

Teknik padanan fungsional saya gunakan untuk menerjemahkan ungkapan ini. Hal ini saya lakukan karena keduanya mengandungi kata slang yang merupakan kata budaya yang tidak ada padanannya dalam BSa. Dalam hal ini saya melakukan dekulturalisasi dengan memadankannya dengan kata BSa yang netral sehingga nuansa slang-nya hilang.

Ungkapan What a honker! dalam konteks ini merupakan kata hinaan. Kata honker sendiri bermakna "nose" (lihat Urbandictionary.com, diakses 7 Februari 2011). Dalam http://dictionary.reference.com/browse/honker (diakses 23 Februari 2011), kata honker bahkan secara spesifik didefinisikan sebagai "slang a nose, esp a large nose". Frasa large nose ini mempertegas pemahaman saya bahwa kata honker memang sebuah kata hinaan.

Dalam konteks ini, yang dihina oleh tokoh Barry adalah hidung lawan bicaranya. Hidung tokoh Hidung Besar ini digambarkan memang besar. Kata honker ini merupakan kata budaya yang tidak ada padanan slang-nya dalam BSa. Oleh karena itu, saya melakukan dekulturisasi terhadap kata honker ini dengan memadankannya dengan ungkapan wah, hidungnya besar sekali! Dengan pemadanan semacam ini, diharapkan terjemahannya terasa wajar dan berterima dalam bahasa anak.

Tabel 12. Penerjemahan Ungkapan Khusus dengan Teknik Kuplet

\begin{tabular}{llll}
\hline No. & \multicolumn{1}{c}{ TSu } & \multicolumn{1}{c}{ TSa } & Par. \\
\hline \multicolumn{1}{c}{$\begin{array}{l}\text { The longest } \\
\text { bogey-catcher } \\
\text { I'd seen in my } \\
\text { life. }\end{array}$} & $\begin{array}{l}\text { Benar-benar } \\
\text { hidung } \\
\text { paling } \\
\text { megar yang } \\
\text { pernah } \\
\text { kulihat! }\end{array}$ & [360] \\
\hline
\end{tabular}

The longest bogey catcher

Nuansa budaya terasa sangat kuat dalam frasa the longest bogey catcher. Menurut laman Urbandictionary.com (diakses 6 Februari 2011), bogey adalah bentuk slang dari kata booger yang artinya "mucus". Kata mucus dalam LDOCE (2001, 
hlm. 935) bermakna "a liquid produced in parts of your body such as nose". Dengan demikian, bogey catcher berarti "penangkap ingus", sehingga the longest bogey catcher secara harfiah bermakna "penangkap ingus yang paling panjang". Sampai tahap ini saya menerjemahkannya dengan teknik padanan fungsional karena saya melakukan dekulturalisasi terhadap kata bogey dengan memadankannya dengan padanan yang netral/bebas dari nuansa slang, yakni ingus.

Istilah penangkap ingus yang paling panjang terasa kaku dan tidak berterima dalam bahasa anak. Untuk itu saya kemudian melakukan penyesuaian cakupan makna dengan memadankannya bogey catcher dengan hidung saja. Kata longest saya hadirkan dalam ungkapan paling megar karena karena makna dari keseluruhan ungkapan the longest bogey catcher adalah "hidung yang panjang dan besar". Citra ini berusaha saya hadirkan dalam terjemahannya. Kata megar juga merujuk pada ungkapan what a honker sebelumnya, karena paragraf ini memang ditujukan untuk menggambarkan hidung tokoh Hidung Besar. Kehadiran frasa the longest bogey catcher adalah untuk memperkuat citra "hidung besar" ini. Ini berarti citra ini harus ditampilkan dalam terjemahannya dengan ungkapan yang sepadan. Kata megar yang dalam KBBI (2008, hlm. 1004) bemakna " a mekar; berkembang" saya anggap sepadan dengan ungkapan honker dan the longest bogey-catcher.

Lebih lanjut, pemadanan the longest bogey cacther menjadi hidung paling megar ini menggunakan teknik modulasi. Terjadi perubahan cakupan makna dalam pemadanan ini dari konsep the longest menjadi paling megar dan bukannya paling panjang. Dengan demikian, secara keseluruhan penerjemahan the longest bogey catcher menggunakan teknik kuplet karena memanfaatkan dua teknik sekaligus.

\section{KESIMPULAN}

Dari 15 kata dan ungkapan budaya yang dianotasi, ditemukan bahwa pemadanan dengan keterangan tambahan adalah teknik yang paling sering digunakan dalam menerjemahkan kata dan ungkapan budaya di dalam TSu, yakni sebanyak empat kali. Teknik penerjemahan terkerap kedua adalah padanan deskriptif, padanan fungsional, dan kuplet, masing-masing tiga kali. Transferensi, padanan fungsional, padanan budaya, dan padanan fonologis menempati tempat ketiga, masing-masing satu kali. Adapun teknik adaptasi sama sekali tidak ditemukan.

Dari temuan ini, dapat ditarik kesimpulan bahwa menunjukkan bahwa kata dan ungkapan budaya dalam TSu seringkali tidak memiliki padanan leksikalnya dalam BSa (bahasa sasaran). Hal ini menyebabkan penerjemahannya menggunakan pemadanan dengan keterangan tambahan. Dan karena teknik ini lebih banyak digunakan, maka kata atau ungkapan budaya tersebut kehilangan nuansa asingnya ketika hadir di dalam terjemahannya. Hal ini terpaksa dilakukan demi menyesuaikan dengan laras bahasa dan ragam bahasa anak di budaya sasaran.

\section{DAFTAR PUSTAKA}

[1] "ANZAC Day". (t.t). http://www.nzhistory.net.nz/war/anzacday/in troduction. (Diakses pada 23 November 2010)

[2] Bassnett, S. 2003. Translation studies (ed. ke-3). London: Routledge.

[3] BoysBrigadeNewZealand. (t.t). "Boys' brigade". $\quad$ http://www.bb.org.nz/about/. (Diakses pada 11 Januari 2011)

[4] "Boys' brigade". (t.t). http://www.sabdaspace.org/boys brigade.

(Di akses pada 11 Januari 2011)

[5] "Crimewatch".

http://www.bbc.co.uk/crimewatch/aboutcrim ewatch/about the show.html.(Diakses pada 5 Januari 2010)

[6] Ensiklopedia Britannica Online. (t.t). "Children's literature". http://www.britannica.com/EBchecked/topic 1111289/childrens-literature. (Diakses pada 15 November 2010)

[7] Ensiklopedia Britannica Online. (t.t). "Whiteware".http://www.britannica.com/EB checked/topic/whiteware. (Diakses pada 19 Mei 2011)

[8] "Flanders poppy". (t.t). http://www.nzembassy.com/belgium/relation ship-between-new-zealand-andbelgium/new-zealand-and-belgium/warcommemorations-bel-1. (Diakses pada 17 Februari 2011)

[9] t.t). "Muesli bar". http://www.thefreedictionary.com/mueslitb ar. (Diakses pada 23 Januari 2011) 
[10] Hatim, B., \& J. Munday. 2004. Translation: an advanced resource book. London: Routledge.

[11] "Half-pipe". (t.t). http://www.merriamwebster.com. (Diakses pada 3 Januari 2011)

[12] Hidayat, R. S. 2010. Penulisan ilmiah bidang linguistik. Catatan. Depok: Program Magister Linguistik, Program Pascasarjana Fakultas Ilmu Pengetahuan Budaya, Universitas Indonesia.

[13] Hoed, B. H. 2006. Penerjemahan dan kebudayaan. Jakarta: Pustaka Jaya.

[14] "Honker". http://dictionary.reference.com/browse/honk er. (Diakses pada 23 Februari 2011)

[15] Hunt, P. 1994. An introduction to children's literature. Oxford: Oxford University Press.

[16] Israël, F. 1996. Makna, bentuk, efek: ancangan komunikatif dalam penerjemahan susastra. (R.S. Hidayat, Penerjemah). Depok: Universitas Indonesia.

[17] "Kaserol". (t.t). http://saossambal.blogspot.com/2008/04/kas erol-roti.html. (Diakses 10 Mei 2011)

[18] Keraf, G. 2001. Diksi dan gaya bahasa: komposisi lanjutan I (edisi yang diperbarui). Jakarta: Gramedia Pustaka Utama.

[19] Lefevere, A. 2004. "Mother courage's cucumbers: text, system and refraction in a theory of literature". Dalam L. Venuti (ed). A translation studies reader (ed. ke-2). (hlm. 239-255). New York: Routledge.

[20] Longacre-Online. (t.t) "About the Author". http://www.longacre.co.nz/authors/mckay.ht $\underline{m l}$. (Diakses pada 23 September 2010)

[21] Machali, R. 2009. Pedoman bagi penerjemah. Bandung: Kaifa.

[22] Miller, J. R. (t.t) Christian Manliness. http://www.gracegems.org/Miller/Christian _manliness.htm. (Diakses pada 12 Januari 2011)

[23] "Muesli". http://www.wisegeek.com/what-ismuesli.htm. (Diakses pada 26 Februari 2011)

[24] Murphy, N. "Dairy". 5 Maret 2011. Komunikasi pribadi.

[25] Murphy, N. "White-ware". 19 Mei 2011. Komunikasi Pribadi.

[26] Newmark, P. 1988. A textbook of translation. London: Prentice Hall.

[27] Anon. 1991. About translation. Clevedon: Multilingual Matters Ltd.

[28] New Zealand Book Council. (t.t) "McKay, Sandy: In Brief'. http://www.bookcouncil.org.nz/writers.mcka ysandy.html.(Diakses 5 Oktober 2010)

[29] Nida, E. \& C. Taber. 1974. The theory and practice of translation. London: EJ Briel.

[30] "Olly". http://www.dictionarist.com/olly. (Diakses pada 24 Januari 2011)

[31] "Poppies".

http://www.nzhistory.net.nz/war/anzacday/poppies. (Diakses pada 23 November 2010)

[32] Putra, P. P. "Half-pipe”. 21 Februari 2011. Komunikasi pribadi.

[33] Putra, P. P. “Olly”. 5 Februari 2011. Komunikasi pribadi.

[34] Sant, B. "Anjing pug". http://www.anjingkita.com/wmview.php?Ar $\underline{\mathrm{tID}=3669}$. 5 Maret 2004. (Diakses pada 7 Februari 2011)

[36] Sarumpaet, R. K. 1975. Bacaan anak-anak: suatu penyelidikan pendahuluan ke dalam hakekat, sifat, dan corak bacaan anak-anak serta minat anak pada bacaannya. Skripsi. Depok: Universitas Indonesia.

[37] Sarumpaet, R. K. 2010. Pedoman penelitian sastra anak. Jakarta: Pustaka Obor.

[38] Snell-Hornby, M. 1995. Translation studies: an integrated approach (ed. yang direvisi). Amsterdam: John Benjamins.

[39] "Staffy bull terrier". (t.t). http://id.88db.com/Hewan-Peliharaan/JualBeli-Hewan/ad.241925. (Diakses pada 21 Februari 2011)

[40] Storylines. (t.t) "Sandy McKay". http://www.storylines.org.nz/Profiles/Profile $s=1-M / S a n d y+M c K a y . h t m l$. (Diakses pada 5 Oktober 2010)

[41] Sugiyono. 2010. Metode penelitian kuantitatif, kualitatif, dan $R \& D$. Bandung: Alfabeta.

[42] "Tell tale tit, your tongue shall be split, and the little puppy dogs shall have a little bit". (t.t).html.hist.no/PROSJEKT/Engnett/songar .doc. (Diakses pada 18 Februari 2011)

[43] Urban Dictionary. (t.t). "Bogey". http://www.urbandictionary.com/define.php ?term=bogey. (Diakses pada 6 Februari 2011)

[44] Urban Dictionary. (t.t). "Chook". http://www.urbandictionary.com/define.php ?term=chook. (Diakses pada 5 Februari 2011)

[45] Urban Dictionary. (t.t). "Honker". http://www.urbandictionary.com/define.php 
?term=honker. (Diakses pada 5 Februari 2011)

[47] Vinay, J., \& J. Darbelnet. 2004. "A methodology for translation." Dalam L. Venuti (ed). A translation studies reader (ed. ke-2). (hlm. 128-137). New York: Routledge.

[48] Webster's Online Dictionary. (t.t). "Rissole".http://www.webster-onlinedictionary.org/definition/rissole?cx=partner -pub-0939450753529744\%3Av0qd01tdlq\&cof $=$ FORID\%3A9\&ie+UTF-

$8 \& q=$ rissole $\&$ sa $=$ Search $\# 906 . \quad$ (Diakses pada 26 Februari 2011)

[49] Wheelers. (t.t). "Books in the kiwi bites series".http://www.wheelers.co.nz/browse/se ries. (Diakses pada 21 Juli 2010)

[50] Wikipedia. (t.t). "Casserole".http://en.wikipedia.org/wiki/Ca sserole.(Diakses pada 26 Februari 2011)

[51] Wikipedia. (t.t). "Children's literature". http://en.wikipedia.org/wiki/Children\%27s l iterature. (Diakses pada 15 November 2010)

[52] Wikipedia. (t.t). "Dachshund". http://id.wikipedia.org/wiki/Dachshund.(Dia kses pada 11 Januari 2011)

[53] Wikipedia. (t.t). "Dairy". http://en.wikipedia.org/wiki/Dairy. (Diakses pada 4 Maret 2011)

[54] Wikipedia. (t.t). "Guinea pig". http://en.wikipedia.org/wiki/Guinea_pig.(Di akses pada 7 Desember 2011)

[55] Wikipedia. (t.t). "Poppy". http://en.wikipedia.org/wiki/Poppy. (Diakses pada 23 November 2010)

[56] Wikipedia. (t.t). "Pug". http://id.wikipedia.org/wiki/pug.(Diakses pada 11 Januari 2011)
[57] Wikipedia. (t.t). "Risoles". http://id.wikipedia.org/wiki/Risoles.(Diakses 10 Mei 2011)

[58] Wikipedia. (t.t). "Rissole". http://en.wikipedia.org/wiki/Rissole.(Diakse s pada 10 Mei 2011)

[59] Wikipedia. (t.t). "The staffordshire bull terrier".http://en.wikipedia.org/wiki/stafford shire_Bull_Terrier. (Diakses pada 2 Desember 2010)

[60] Wikipedia. (t.t). "The Macquarie Dictionary".http://en.wikipedia.org/wiki/Ma cquarie_Dictionary.(Diakses pada 23 Desember 2010)

[61] Wikipedia. (t.t). "Tikus belanda". http://id.wikipedia.org/wiki/Tikus_belanda.( Diakses 7 Desember 2010)

[62] Wikipedia. (t.t). "Superette". http://id.wikipedia.org/wiki/Superette.(Diaks es pada 4 Maret 2011)

[63] Wiktionary. (t.t). "Dairy". http://en.wiktionary.org/wiki/dairy.(Diakses pada 4 Maret 2011)

[64] Wiktionary. (t.t) "Whiteware".http://en.wiktionary.org/wiki/ whiteware. (Diakses pada 19 Mei 2011)

[65] Williams, J., \& A. Chesterman. 2002. The map. A beginner's guide doing research in translation studies. Manchester: St. Jerome Publishing.

[67] Zed, M. 2014. Metode penelitian kepustakaan. Jakarta: Yayasan Pustaka Obor Indonesia. 